\author{
RESEARCH ARTICLE \\ 10.1029/2019JB017490 \\ Key Points: \\ - A-type Qitianling magmas were \\ produced at high temperature $(>900$ \\ ${ }^{\circ} \mathrm{C}$ ) and with initial $\mathrm{H}_{2} \mathrm{O}_{\text {melt }} \geq 4$ wt \% \\ - Crystallization of Qitianling granites \\ occurred at $\geq 300-350 \mathrm{MPa}$, NNO \\ $-1.3 \pm 0.5$, and near-solidus $\mathrm{H}_{2} \mathrm{O}_{\text {mel }}$ \\ $\geq 6.5-8.0 \mathrm{wt} \%$ \\ - Fractionation of the magmas \\ occurred at or close to the level of \\ final emplacement and \\ crystallization
}

Supporting Information:

- Supporting Information S1

Correspondence to:

B. Scaillet and R. Wang,

bruno.scaillet@cnrs-orleans.fr;

rcwang@nju.edu.cn

Citation:

Huang, F., Scaillet, B., Wang, R., Erdmann, S., Chen, Y., Faure, M., et al. (2019). Experimental constraints on intensive crystallization parameters and fractionation in A-type granites: A case study on the Qitianling Pluton, South China. Journal of Geophysical Research: Solid Earth, 124. https://doi.org/ 10.1029/2019JB017490

Received 2 FEB 2019

Accepted 28 AUG 2019

Accepted article online 4 SEP 2019

(C)2019. American Geophysical Union. All Rights Reserved.

\section{Experimental Constraints on Intensive Crystallization Parameters and Fractionation in A-Type Granites: A Case Study on the Qitianling Pluton, South China}

\author{
Fangfang Huang ${ }^{1,2}$, Bruno Scaillet ${ }^{2}$ (D), Rucheng Wang1 ${ }^{1}$, Saskia Erdmann ${ }^{2}$, Yan Chen ${ }^{2}$, \\ Michel Faure ${ }^{2}$, Hongsheng Liu ${ }^{1,2}$, Lei Xie ${ }^{1}$, Bo Wang ${ }^{1}$ (D), and Jinchu Zhu ${ }^{1}$ \\ ${ }^{1}$ State Key Laboratory for Mineral Deposits Research, School of Earth Sciences and Engineering, Nanjing University, \\ Nanjing, China, ${ }^{2}$ Institut des Sciences de la Terre d'Orléans (ISTO), Université d'Orléans-CNRS-BRGM, UMR 7327, \\ Orléans, France
}

\begin{abstract}
Phase equilibrium experiments are essential for robustly and accurately constraining the intensive parameters of magma systems and their fractionation history, which is particularly true for A-type granites crystallized from $\mathrm{H}_{2} \mathrm{O}$-rich melts and at reducing conditions. Here, we constrain the crystallization conditions of the ferroan (A-type), Sn-mineralized Qitianling granite of South China, which formed during a major event of crustal formation and reorganization in the Mesozoic. To characterize the magma system conditions and fractionation, we have carried out a series of experiments on three representative, amphibole-bearing samples. The experiments were performed at 100-700 MPa (mainly at 200 and $300 \mathrm{MPa}$ ), at an $\mathrm{fO}_{2}$ of $\sim \mathrm{NNO}-1.3$ (1.3 log unit below the Ni-NiO buffer) or $\sim \mathrm{NNO}+2.4$, at 660 to 900 ${ }^{\circ} \mathrm{C}$, and at variable $\mathrm{H}_{2} \mathrm{O}_{\text {melt }}(\sim 3-9 \mathrm{wt} \%)$. They show that the Qitianling magmas last crystallized at $\geq 300-350 \mathrm{MPa}$, at a $\mathrm{H}_{2} \mathrm{O}_{\text {melt }} \geq 6.5-8.0 \mathrm{wt} \%$, and that magmatic $f_{2}$ was $\sim \mathrm{NNO}-1.3 \pm 0.5$ at above-solidus conditions. Amphibole texture in the rocks suggests an early crystallization of this mineral, hence that water-rich ( $\geq 4$ wt $\% \mathrm{H}_{2} \mathrm{O}$ in melt) conditions prevailed early during the magmatic evolution, prior to amphibole crystallization. At all investigated conditions, amphibole crystallization requires at least 5-6 wt \% dissolved $\mathrm{H}_{2} \mathrm{O}$, being even absent in the more potassic composition. We interpret this as resulting from the elevated $\mathrm{K}_{2} \mathrm{O}$ content of the investigated compositions that inhibits amphibole crystallization in metaluminous granitic systems. The experimental liquid line of descent obtained at 200-300 MPa mimics the geochemical trend expressed by the pluton suggesting that fractionation occurred in the upper crustal reservoir.
\end{abstract}

\section{Introduction}

Large-scale partial melting of the continental crust results from major geodynamic events such as subduction, continental collision, mantle plume impingement, or intracontinental rifting (Annen et al., 2006; Campbell \& Griffiths, 1990; Defant \& Drummond, 1990; Li \& Li, 2007; Thompson \& Connolly, 1995). Rocks exposed in South China provide an intriguing window into continental crust that has experienced extensive A-, I-, and S-type granite magmatism and associated ore deposit formation (Chen et al., 2013; Hua et al., 2005; Mao et al., 2010, 2013). Mesozoic ( 66-251 Ma) granitic rocks (sensu lato) make up a large proportion ( $60 \%$ ) of the exposed crust, with an overall exposure of $\sim 135,000 \mathrm{~km}^{2}$, classifying as a large, felsic igneous province (Figure 1a; e.g., Zhou et al., 2006). Such huge volumes of granitic intrusions are rare outside arcs, recording a major event of crustal reorganization and formation. The intensive parameters of the magmatism and thus source conditions remain, however, poorly constrained while it is unanimously suggested that mafic magma underplating was significant (He et al., 2010; Xia et al., 2014).

Jurassic plutons ( 142-180 Ma) comprise the largest proportion ( 50\%) of the exposed intrusions, and they thus represent the peak of crustal growth and reorganization during Mesozoic in South China. Many of the Jurassic plutons are moreover associated with world-class rare metal (Sn, W, Nb, Ta, Zr, U, and REE) deposits (Chen et al., 2013; Mao et al., 2013; Wang et al., 2017, 2013; Zhu et al., 2008). The Qitianling intrusion, one of the main Jurassic A-type granites (ferroan, Sn-mineralized; Figure 1), was incrementally built over several million years ( 163-146 Ma), as shown by our previous field, geophysical (gravimetric), and laboratory constraints (magnetic mineralogy, AMS, geochronology) combined with published age data (Liu et al., 2018). But what were the intensive parameters of granite crystallization (P-T- $f \mathrm{O}_{2}$-melt volatile contents) and source partial melting, and where did fractionation take place? Building on previous constraints and models of 

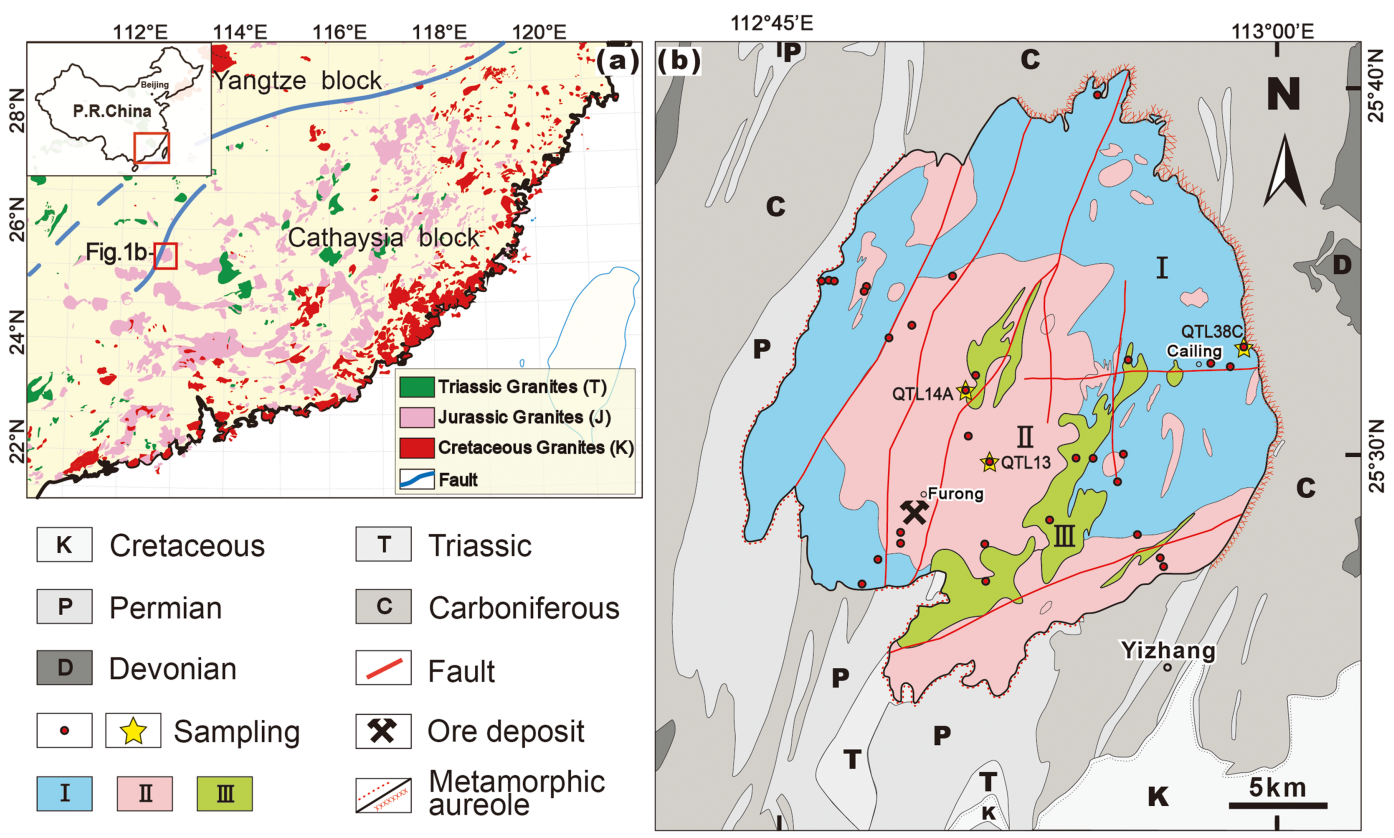

Figure 1. (a) Simplified geological map of Southeast China showing the distribution of Triassic to Cretaceous granites (modified after Zhou et al., 2006) and (b) geological map of the Qitianling pluton (modified after Zhu et al., 2009). Samples from outcrop locations highlighted by stars were selected for our experimental petrology study. I = Phase 1, porphyritic, medium- to coarse-grained amphibole-biotite-rich granite; II $=$ Phase 2 , medium-grained biotite \pm amphibole-bearing granite; III = Phase 3, fine-grained, biotite-bearing granite.

granite evolution, we have carried out phase equilibrium experiments to robustly constrain the intensive parameters of crystallization for the A-type granites. We present (1) a petrological and geochemical overview on the Qitianling pluton; and (2) results from our phase equilibrium experiments; followed by a discussion of (3) the intensive crystallization parameters; and (4) processes underlying the geochemical variation of the pluton. We highlight that phase equilibrium constraints are crucial for deriving reliable estimates for crystallization temperatures, melt $\mathrm{H}_{2} \mathrm{O}$ content, and $\mathrm{fO}_{2}$ for ferroan A-type granites, and thus for unraveling Mesozoic crust formation and evolution in South China.

\section{Geological Setting}

The Qitianling granite crops out in the southeast of China (Figure 1) within the South China Block (SCB), which was formed by the amalgamation of the northwest Yangtze and southeast Cathaysia blocks $\sim 850$ Ma ago (Wang et al., 2006, 2007). The SCB has experienced various tectonometamorphic events during the Early Paleozoic and Triassic (Chu et al., 2012; Faure et al., 2008, 2014; Liu et al., 2018; Shu et al., 2011; Zhang et al., 2013), but evidence for ductile or syn-emplacement deformation of the Jurassic plutons in the SCB is conspicuously absent (Feng et al., 2012; Liu et al., 2018). The Jurassic, 146-163 Ma Qitianling pluton forms a $\sim 25-\mathrm{km}$-wide and $\sim 5$-km-deep lopolith, which is exposed in a near-roof section (Liu et al., 2018). It intruded Carboniferous to Triassic carbonates and sandstones, lying close to the NNE-SSW trending Chenzhou-Linwu crustal fault (Figure 1; Wang et al., 2003; Zhao et al., 2012). Exposed contacts between the Qitianling granite and its country rocks are sharp with narrow metamorphic aureoles (typically $<30 \mathrm{~m}$ wide, Liu et al., 2018), which are characterized by biotite-muscovite hornfels (in the east), garnet-bearing skarns (in the northeast), and marbles (in the southwest).

The exposed pluton, which is inferred to have been incrementally built (Liu et al., 2018), constitutes three main rock types (phases; Xie et al., 2009; Zhu et al., 2009): (1) porphyritic, medium- to coarse-grained amphibole-biotite-rich monzonitic granite (Phase 1, 45\% of the exposure); (2) medium-grained biotite \pm amphibole-bearing granite (Phase 2; $40 \%$ of the exposure); and (3) a fine-grained, biotite-bearing granite (Phase $3 ; \sim 15 \%$ of the exposure; Figure 1b). Mafic microgranular enclaves (MMEs) with sizes between several centimeters to decimeters also locally occur, mostly in the Phase 1 granite (Zhao et al., 2012). The Phase 1 granite comprises plagioclase ( $\sim 30 \%)$, K-feldspar ( 30\%), quartz ( 25\%), amphibole $(\sim 5 \%)$, biotite ( 8\%), 


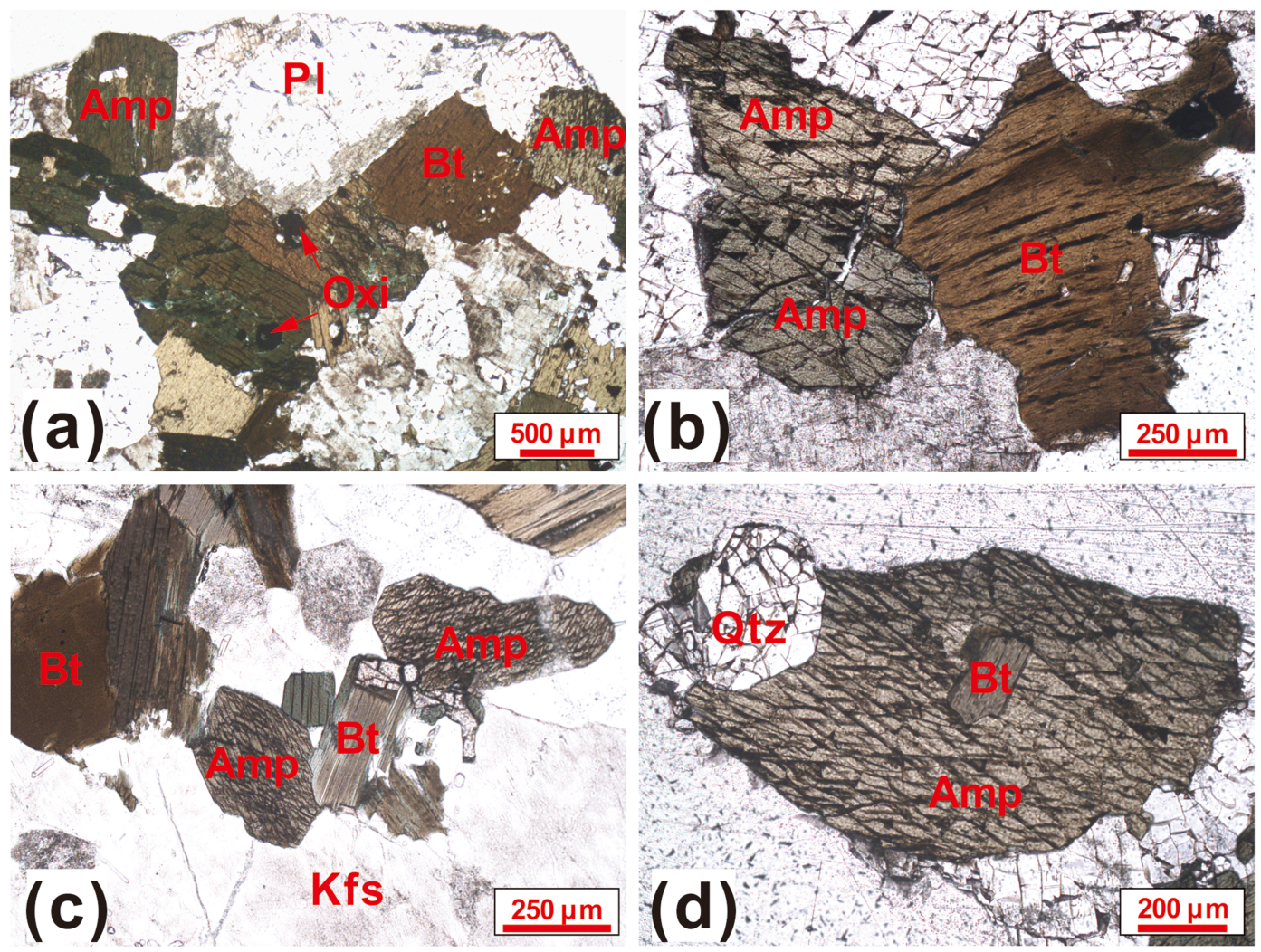

Figure 2. Microphotographs of Qitianling amphibole-biotite granite (Phase 1). (a) to (c) Sharp contacts between amphibole and biotite. (d) Euhedral to subhedral biotite observed as an apparent inclusion in amphibole. Abbreviations: Amp: amphibole; Bt: biotite; Pl: plagioclase; Oxi: Fe-Ti oxides; Kfs: K-feldspar; Qtz: quartz.

and accessory minerals including milmenite geothermometer and oxygen barometer, ilmenite, apatite, zircon, and titanite. The Phase 2 granite has plagioclase ( 30\%), K-feldspar $(\sim 35 \%)$, quartz $(\sim 25 \%)$, biotite $(\sim 7 \%)$, and amphibole $(<3 \%)$. The Phase 3 granite contains plagioclase $(\sim 30 \%)$, K-feldspar $(\sim 35 \%)$, quartz $(\sim 30 \%)$, and biotite $(<5 \%)$. Amphibole, biotite, plagioclase, and K-feldspar are subhedral to euhedral in all granite types. Amphibole and all other phases, including biotite, also share sharp contacts, showing that both are not late, interstitially crystallizing phases (Figure 2). Biotite also forms inclusions in amphibole (Figure 2), while inclusions of amphibole in biotite are rare (representative mineral compositions are given below along with the experimental mineral compositions).

The composition of the Qitianling granites and their mineral assemblages have already been extensively studied (e.g., Deng et al., 2005; Xie et al., 2013; Zhao et al., 2005, 2012; Zhu et al., 2003, 2005, 2009). The whole rocks have $\mathrm{SiO}_{2}$ contents between $\sim 65$ and $\sim 77 \mathrm{wt} \%$, increasing from Phase 1 to Phase 3 (Table S1 in the supporting information). They are metaluminous to weakly peraluminous ( $\mathrm{A} / \mathrm{CNK}=\operatorname{mol} \% \mathrm{Al}_{2} \mathrm{O}_{3}$ / $\left(\mathrm{CaO}+\mathrm{Na}_{2} \mathrm{O}+\mathrm{K}_{2} \mathrm{O}=\sim 0.83-1.09\right)$, ferrous $(\mathrm{FeO} /(\mathrm{FeO}+\mathrm{MgO})=0.78-0.98)$, and alkali-rich $\left(\mathrm{Na}_{2} \mathrm{O}+\right.$ $\left.\mathrm{K}_{2} \mathrm{O}=\sim 6.9-9.6 \mathrm{wt} \%\right)$ with elevated $\mathrm{K}_{2} \mathrm{O} / \mathrm{Na}_{2} \mathrm{O}$ ratios $(\sim 1.3-2.4)$. The $\mathrm{F}$ content of the Qitianling granites varies between $\sim 0.06$ and $0.6 \mathrm{wt} \%$, increasing from the Phase 1 to the Phase 3 granites (from $\sim 0.16 \mathrm{wt} \%$ over $\sim 0.20 \mathrm{wt} \%$ to $\sim 0.38 \mathrm{wt} \%$ on average). The granites also have high $\mathrm{Rb}, \mathrm{Th}, \mathrm{Zr}$, and $\mathrm{Y}$ contents, while $\mathrm{Sr}$, $\mathrm{Ba}, \mathrm{P}$, and $\mathrm{Ti}$ are relatively low. The $(\mathrm{La} / \mathrm{Yb})_{\mathrm{N}}$ ratios $(21.3$ on average) and the $10,000 *(\mathrm{Ga} / \mathrm{Al}) n$ ratios $(3.2$ on average) are both relatively high (Table S1).

\section{Experimental Background, Experimental and Analytical Strategy, and Analytical Techniques}

\subsection{Experimental Background}

The conventional method for constraining the crystallization conditions of granite bodies is to use experimentally or empirically calibrated geothermometers, geobarometers, and oxybarometers (e.g., Anderson, 
1996; Anderson et al., 2008; Hammarstrom \& Zen, 1986; Mutch et al., 2016; Putirka, 2016). Such an approach does, however, bear large uncertainties, especially for granites with weakly metaluminous to weakly peraluminous compositions and for ferroan and other granites that have crystallized at relatively reducing conditions, as none of the available geothermometers, geobarometers, and oxybarometers have been calibrated on their compositions or for relatively reducing conditions $(\leq \mathrm{NNO}+1)$. Calibrations for accurately constraining melt water content are moreover not available. Robust and accurate constraints on the intensive parameters of crystallization can, however, be derived from phase equilibrium experiments performed on representative compositions (e.g., Clemens \& Wall, 1981; Clemens et al., 1986; Dall'Agnol et al., 1999; Klimm et al., 2003; Scaillet et al., 1995). Phase equilibria for an A-type granite were first established by Clemens et al. (1986) for the metaluminous Watergums granite from southeastern Australia. The experimental work of Dall'Agnol et al. (1999), Bogaerts (2003), Bogaerts et al. (2006), and Klimm et al. $(2003,2008)$ have subsequently constrained emplacement conditions for other metaluminous A-type or ferroan granites. These studies have shown that the precursor magmas of such granites have relatively high temperatures $\left(>800{ }^{\circ} \mathrm{C}\right)$, that they have crystallized at a wide range of pressures $(\sim 100-400$ $\mathrm{MPa})$, at melt water contents of up to $6.5 \mathrm{wt} \%$ and at redox conditions between $\sim \mathrm{NNO}$ and $\sim \mathrm{NNO}+1$ (Clemens \& Wall, 1981; Dall'Agnol et al., 1999; Klimm et al., 2003). The phase equilibrium experiments of Klimm et al. (2003, 2008) also explored the relationship between variably evolved monzogranitic plutons of the Wangrah Suite A-type granites, suggesting that they are related by crystal fractionation.

\subsection{Experimental Strategy}

With our strategy, we follow (1) the experimental approach of previous studies to constrain the intensive parameters of crystallization (P-T-melt $\mathrm{H}_{2} \mathrm{O}-\mathrm{fO}_{2}$ ) for the Qitianling pluton and (2) the experimental approach of Klimm et al. (2008) using three representative and variably evolved samples of the granite intrusion to examine their fractionation relation.

Our choice of experimental conditions for the conventional phase equilibrium experiments is based on P-T estimates gathered from previous studies and our own data. Calculated zircon saturation temperatures for the Qitianling granites are between $~ 715$ and $875^{\circ} \mathrm{C}$ (Table $\mathrm{S} 1$ and Zhao et al., 2005), which is in the range typical for alkali-rich granitic magmas (e.g., cf. Collins et al., 2016). Zr-in-titanite thermometry of euhedral titanite crystal cores records crystallization at $\sim 720-780{ }^{\circ} \mathrm{C}$, while rim and thus final granite crystallization temperatures remain unconstrained (Xie et al., 2010). Hornblende-plagioclase and hornblende thermobarometry (Anderson \& Smith, 1995; Hammarstrom \& Zen, 1986; Holland \& Blundy, 1994; Hollister et al., 1987; Johnson \& Rutherford, 1989; Schmidt, 1992) yield high crystallization temperatures of $\sim 750-820^{\circ} \mathrm{C}$ and high crystallization pressures of $\sim 360 \pm 90 \mathrm{MPa}$ (Zhao et al., 2005), but the employed amphibole thermometers are inadequate for the composition of amphibole present in the Qitianling granites (with calculated $\mathrm{Fe}^{3+} /\left[\mathrm{Fe}^{3+}\right.$ $\left.+\mathrm{Fe}^{2+}\right]$ of $\leq 0.20-0.25$; cf. Anderson \& Smith, 1995; Holland \& Blundy, 1994). All amphibole barometers available for granitic compositions have moreover been calibrated on calcic whole-rock compositions and for crystallization at oxidizing conditions ( $>\mathrm{NNO}+1$, typical for arc systems), and thus for intensive parameters that likely differed from those of the Qitianling magma system. Therefore, the calculated high crystallization temperatures and pressures need to be critically assessed (Erdmann et al., 2014).

The common presence of milmenite geothermometer and oxygen barometer together with ilmenite and the composition of biotite (Fe-rich) have been used to infer magmatic crystallization over a wide range of oxygen fugacities, between the NNO and the $\mathrm{MH}\left(\mathrm{Fe}_{2} \mathrm{O}_{3}-\mathrm{Fe}_{3} \mathrm{O}_{4}\right)$ buffers (Wang et al., 2017; Zhao et al., 2005). Whether this wide range of estimated redox conditions reflects the uncertainty of the methods, or if oxygen fugacity varied widely spatially or temporally, remains poorly understood. The compositions of spatially associated milmenite geothermometer and oxygen barometer and ilmenite in samples of the main Phase 1 and Phase 2 granites (which we have analyzed using a broad electron beam to acquire average compositions) suggest equilibration below the solidus at $\sim 580^{\circ} \mathrm{C}$ at an oxygen fugacity around NNO+1 (Table S2). The melt $\mathrm{H}_{2} \mathrm{O}$ and other volatile contents $\left(\mathrm{F}, \mathrm{Cl}, \mathrm{CO}_{2}\right)$ of the Qitianling magmas remain unconstrained, although the presence of amphibole suggests melt $\mathrm{H}_{2} \mathrm{O}$ contents of $\geq 4$ wt \% (e.g., cf. Dall'Agnol et al., 1999; Naney, 1983).

According to these estimates and unknowns, experimental temperature and pressure were varied over a wide range between 660 and $900{ }^{\circ} \mathrm{C}$ and between $\sim 100$ and $\sim 700 \mathrm{MPa}$, respectively (Table S3). Most experiments were carried out at $\sim 200$ and $300 \mathrm{MPa}$, but additional experiments were performed at $\sim 100, \sim 400$, and $\sim 700 \mathrm{MPa}$. Oxygen fugacity was varied between $\sim \mathrm{NNO}+2.4$ and $\sim \mathrm{NNO}-4.0$, though most experiments were 
performed at $\sim \mathrm{NNO}+2.4$ (at "oxidizing" conditions) and at $\sim \mathrm{NNO}-1.3$ (at "reducing conditions"; Table S4). Melt $\mathrm{H}_{2} \mathrm{O}$ content was varied between $\sim 3.0$ and $\sim 8.6 \mathrm{wt} \%$ by varying pressure and fluid $\mathrm{H}_{2} \mathrm{O}$ and $\mathrm{CO}_{2}$ composition $\left(\mathrm{XH}_{2} \mathrm{O}\right.$; see below). Nineteen experiments were performed with a total of 166 individual charges (Table S4). Experiments performed above $800^{\circ} \mathrm{C}$ lasted for $\sim 140-350 \mathrm{hr}$ ( $\sim 6-15$ days), while those performed below $800{ }^{\circ} \mathrm{C}$ lasted for $\sim 470-1350 \mathrm{hr}$ ( 20-56 days).

\subsection{Starting Materials and Experimental Equipment}

Three representative and variably evolved samples of the two main Qitianling granite types—one Phase 1 and two Phase 2 samples (Figure 1b)-were chosen as the raw starting materials for our experiments. They show limited subsolidus alteration (chloritization, albitization, sericitization) that affected $<2-5$ vol $\%$ of the mineral assemblage. We did not work on Phase 3 biotite granite because all exposed rocks are severely altered. The selected starting material samples have $\mathrm{SiO}_{2}$ contents of $\sim 65.7 \mathrm{wt} \%$ (Phase 1 granite, sample QTL38C), 68.1 wt \% (Phase 2 granite, sample QTL14A), and 70.9 wt \% (Phase 2 granite, sample QTL13; Table S3). To prepare the glass starting materials for the experiments, powders of the bulk rocks were individually melted twice for $3 \mathrm{hr}$ in air at atmospheric pressure (with grinding in between) in a Pt crucible at $1400{ }^{\circ} \mathrm{C}$ and then quenched in water. The resulting dry glasses were ground to $<20 \mu \mathrm{m}$, which we then used as the starting materials for the experiments. Analyses of several glass chips by electron microprobe (EMP) showed them to be homogeneous, with compositions similar to whole-rock analyses indicating that elemental loss during fusion was negligible (Table S3).

To prepare the experimental charges, deionized water was first loaded into Au capsules $(2.5 / 2.9 \mathrm{~mm}$ inner/outer diameter, $\sim 1.5 \mathrm{~cm}$ long). To vary $\mathrm{XH}_{2} \mathrm{O}\left(\mathrm{mol} \% \mathrm{H}_{2} \mathrm{O} /\left[\mathrm{H}_{2} \mathrm{O}+\mathrm{CO}_{2}\right]\right)$, silver oxalate $\left(\mathrm{Ag}_{2} \mathrm{C}_{2} \mathrm{O}_{4}\right)$ was then added in various amounts (keeping $\mathrm{H}_{2} \mathrm{O}+\mathrm{CO}_{2}$ at $\sim 3 \mathrm{mg}$ ). After $\mathrm{H}_{2} \mathrm{O}$ and silver oxalate, about $30 \mathrm{mg}$ of the dry starting glass powders was loaded to the capsule. The Au capsules were then welded shut and checked for leaks by weighing. The capsules were put into an oven at $120{ }^{\circ} \mathrm{C}$ for several $(>2)$ hours to ensure homogeneous fluid distribution and they were then weighed again to check for capsule integrity. The most oxidizing experiments were buffered at the intrinsic $f \mathrm{H}_{2}$ of the pressure vessel (i.e., at $\sim \mathrm{NNO}$ +2.5; cf. Dall'Agnol et al., 1999). For reducing experiments, solid Co-Pd-O and Ni-Pd-O sensors were prepared to monitor $\mathrm{fO}_{2}$, following the technique of Taylor et al. (1992).

All 19 experiments were performed in internally heated pressure vessels (IHPV) using a Kanthal furnace. Up to 23 capsules, including the sensors, were loaded at once. Experiments at reducing conditions $(\sim \mathrm{NNO}-1.3)$ were pressurized by a mixture of $\mathrm{Ar}-\mathrm{H}_{2}$ gas (Scaillet et al., 1992). Oxidizing runs $(\sim \mathrm{NNO}+2.4)$ were performed using pure Ar gas as the pressure medium. Temperature was then increased and final pressure reached. Temperature was monitored with two S-type thermocouples bracketing the sample holder, with an error of $\pm 5{ }^{\circ} \mathrm{C}$; pressure was monitored with a transducer calibrated against a Heise Bourdon gauge, with an overall uncertainty of $\pm 0.2 \mathrm{MPa}$. All experiments were terminated by switching off the power supply, which decreased temperature to $<100{ }^{\circ} \mathrm{C}$ within $\leq 5 \mathrm{~min}$. After the experiments, all capsules were checked for weight changes to check for leaks. Fragments of the run products recovered from each charge were embedded in epoxy and polished for backscattered electron imaging and electron microprobe analysis.

\subsection{Analytical Methods}

Whole-rock compositions of natural samples were determined including our three raw starting materials (Table S1). The whole-rock major-element compositions were determined by wet-chemical analysis at the Analysis Center of the No. 230 Research Institute of the China National Nuclear Corporation (CNNC), Changsha, China. Whole-rock trace-element compositions were obtained using a Thermo X7 ICP-MS at the State Key Laboratory of Ore Deposit Geochemistry, Institute of Geochemistry, Chinese Academy of Science, Guiyang, China. The analytical packages (Chinese National standard protocol GB/T 14506 (3-14)2010) and procedures are equivalent to those described in detail by Qi et al. (2000) and Huang et al. (2015).

Imaging and phase characterization were performed using two scanning electron microscopes and two electron microprobes: a JEOL JXA-8100M microprobe and a Zeiss scanning electron microscope at the State Key Laboratory for Mineral Deposits Research of Nanjing University, China, and a CAMECA SX-Five and Zeiss scanning electron microscope at the Institut des Sciences de la Terre d'Orléans, France. Repeat analyses were performed on selected run products to ensure that the microprobe analyses performed with the two instruments yielded equivalent results within accepted uncertainties. Quantitative analyses of the natural mineral 
assemblages and all experimental run products were carried out at a $15 \mathrm{kV}$ accelerating voltage, at either 20(China) or 6-nA (France) beam currents, and at a nominal beam diameter of $1 \mu \mathrm{m}$ for minerals and a $10-\mu \mathrm{m}$ beam diameter for glasses or Fe-Ti oxides (ilmenite and milmenite geothermometer and oxygen barometer). Four hydrous rhyolite glass standards (Scaillet \& Evans, 1999) were also analyzed in each session to correct for alkali migration under the electron beam and to calculate the glass $\mathrm{H}_{2} \mathrm{O}$ content of the unknowns (using a corrected-by-difference method, following Scaillet \& Evans, 1999). In addition to the glass (melt) $\mathrm{H}_{2} \mathrm{O}$ contents calculated on the basis of the EMP analyses, nominal melt $\mathrm{H}_{2} \mathrm{O}$ contents were also calculated using VolatileCalc (Newman \& Lowenstern, 2002), using a rhyolite composition, and the $\mathrm{XH}_{2} \mathrm{O}$ values of the individual charges. Melt $\mathrm{H}_{2} \mathrm{O}$ contents calculated with both methods generally agree within \pm 1 wt \% (Table S4), but values calculated on the basis of EMP analyses are scattered owing to analytical errors (in particular in crystal-rich charges). For consistency, we therefore refer to the values calculated using VolatileCalc in text and figures.

Most crystals were large enough for EMP analysis, but crystals in some low-temperature, low- $\mathrm{H}_{2} \mathrm{O}$ charges were too small for uncontaminated analyses (e.g., biotite and oxides). Possible contamination of mineral analyses by matrix glass and/or neighboring minerals was evaluated on the basis of analytical totals (wt \% oxides) and on the basis of the calculated stochiometry. For some charges, despite considerable effort, no uncontaminated compositions could be determined (e.g., charges 01, 02, and 03; Table S4). Phase proportions were calculated by mass balance, whenever possible, and they are summarized in Table S4. We note that for most of the run products, the residuals of the mass balance calculations $\left(\sum r^{2}\right)$ are low $(<0.1)$. For these charges, we estimate that the calculated phase abundances have uncertainties of $\pm 3 \mathrm{wt} \%$. In cases with higher residuals, which reflect some analytical problems, we consider uncertainties of $\pm 5-10 \mathrm{wt} \%$.

Mineral abbreviations used are those of Whitney and Evans (2010). Mineral end-member compositions were calculated as follows: (1) Plagioclase (Pl) anorthite (An) content was calculated as $[\mathrm{Ca} /(\mathrm{Ca}+\mathrm{Na}+\mathrm{K})]^{*} 100$. (2) Pyroxene enstatite (En), ferrosilite (Fs), and wollastonite (Wo) contents were calculated as $[\mathrm{Mg} /(\mathrm{Ca}+\mathrm{Mg}$ $+\mathrm{Fe})]^{*} 100,[\mathrm{Fe} /(\mathrm{Ca}+\mathrm{Mg}+\mathrm{Fe})]^{*} 100$, and $[\mathrm{Ca} /(\mathrm{Ca}+\mathrm{Mg}+\mathrm{Fe})]^{*} 100$, where we distinguish orthopyroxene (Opx, < 5\% Wo), pigeonite (Pgt, 5-20\% Wo), and augite (Aug, 20-45\% Wo). Pyroxene enstatite, diopside ( $>45 \%$ Wo), and hedenbergite ( $>45 \%$ Wo) contents were calculated following Morimoto (1988). We collectively refer to pyroxene with orthopyroxene and pigeonite composition as low-Ca pyroxene (Lpx). (3) Amphibole (Amp) composition was calculated and classified following Leake et al. (1997, 2003). (4) Biotite (Bt) classification follows Rieder et al. (1998). (5) The calculation of ilmenite and ulvöspinel proportions in ilmenite (Ilm) and magnetite (Mag) follows the approach of Stormer (1983).

\section{Experimental Results}

\subsection{Phase Relations}

The phases in our run products are homogeneously distributed. The crystals are euhedral and unzoned, with sizes between $\sim 30$ and $<5 \mu \mathrm{m}$. Phases include low-Ca pyroxene (Lpx), clinopyroxene (Cpx), amphibole (Amp), biotite (Bt), plagioclase (Pl), K-feldspar (Kfs), quartz (Qtz), magnetite (Mag), ilmenite (Ilm), titanite (Ttn), allanite (All), fluid/bubbles (Fl), and glass (Gl). Apart from the most mafic composition, whose $\mathrm{H}_{2} \mathrm{O}$ saturated liquidus temperature is slightly higher than $900{ }^{\circ} \mathrm{C}$ (see below), the experiments encompass liquidus to solidus temperatures at $\mathrm{H}_{2} \mathrm{O}$-rich conditions (Figure 3 ). The majority of phase relations were determined at reducing conditions ( NNO-1.3; Figure 3$)$. At oxidizing conditions, we explored only water saturated conditions at 700 and $800{ }^{\circ} \mathrm{C}$; hence, no attempt has been made to draw the phase equilibria for high $\mathrm{fO}_{2}$.

4.1.1. Phase 1 Amphibole-Biotite Granite

At $200 \mathrm{MPa}$ and NNO-1.3, Lpx, Cpx, Pl, Amp, Kfs, Qtz, Ilm, Mt, and Gl (0-90\%) crystallized from the Phase 1 composition (Table S4; Figure 3a; sample QTL38C, $25 \mathrm{wt} \% \mathrm{SiO}_{2}$ ). Ilm, Lpx, and Cpx are the near-liquidus phases (Figure 3a). Lpx stability is limited to $\geq 750-800^{\circ} \mathrm{C}$, while Cpx is present in all charges except for one Amp-rich charge at $800{ }^{\circ} \mathrm{C}$ and $\mathrm{H}_{2} \mathrm{O}$ saturation. Amp appears at $<900{ }^{\circ} \mathrm{C}$ and $\mathrm{at}_{2} \mathrm{O}_{\text {melt }}>5.5$ wt $\%$, but its appearance is limited to $>700-750^{\circ} \mathrm{C}$, i.e., Amp is not a stable solidus or near-solidus phase at $200 \mathrm{MPa}$. Amp thus has a remarkably narrow stability field at $200 \mathrm{MPa}$ (Figure 3a). Bt appears below $900^{\circ} \mathrm{C}$ and is stable over the entire range of explored $\mathrm{H}_{2} \mathrm{O}_{\text {melt }}$ (i.e., 3-6.4 wt \%). $\mathrm{Pl}$ crystallizes below $900^{\circ} \mathrm{C}$ at low $\mathrm{H}_{2} \mathrm{O}_{\text {melt }}$ ( $<4$ wt \%) and below $825^{\circ} \mathrm{C}$ at $\mathrm{H}_{2} \mathrm{O}$ saturation. The Qtz and $\mathrm{Kfs}$ saturation curves are subparallel to the $\mathrm{Pl}$ 

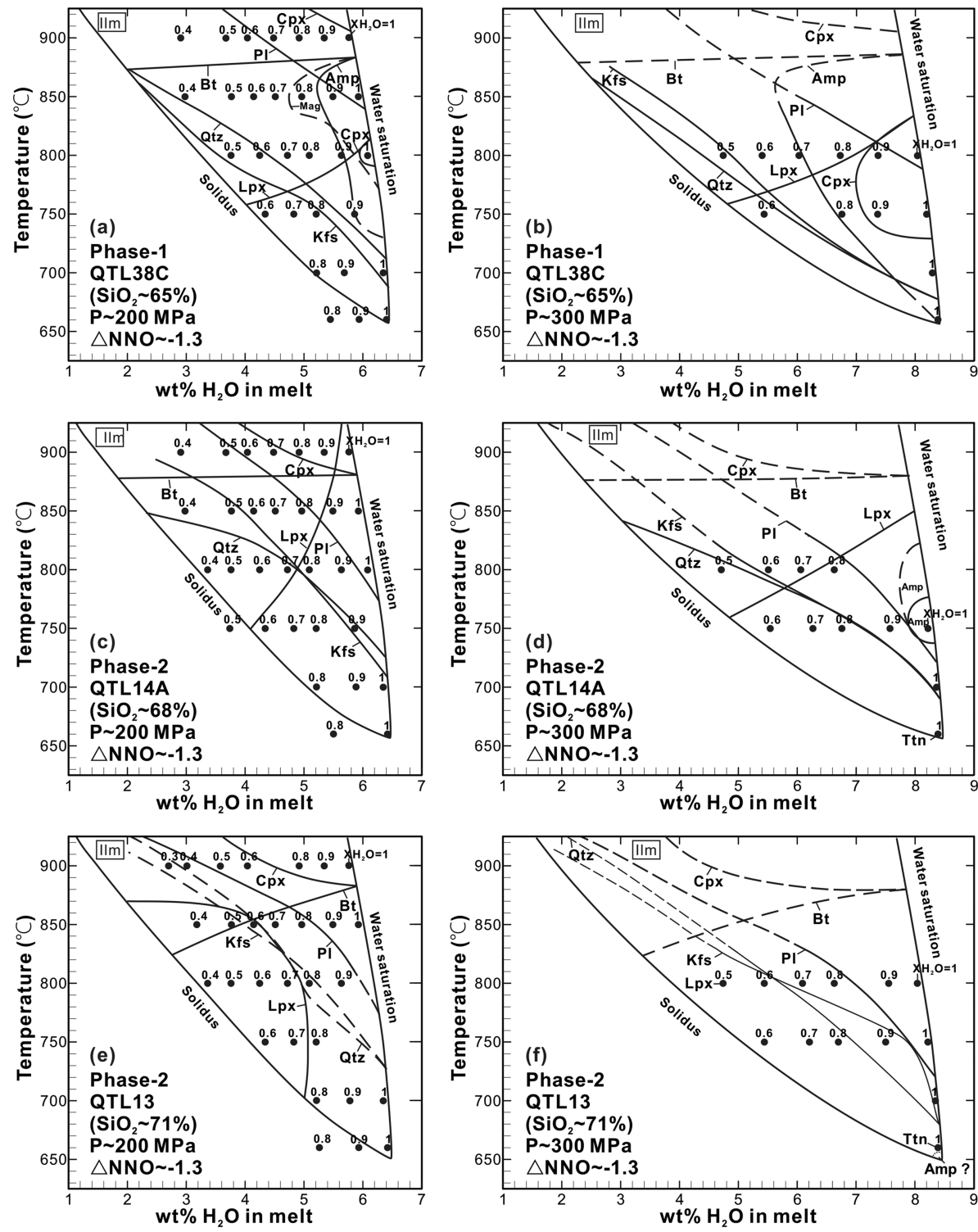

Figure 3. Isobaric phase diagrams at 200 and $300 \mathrm{MPa}$ for the three granite compositions ([a, b] QTL38C; [c, d] QTL14A; [e, f] QTL13) as a function of temperature and melt $\mathrm{H}_{2} \mathrm{O}$ content. The inset numbers are $\mathrm{XH}_{2} \mathrm{O}=\left[\mathrm{H}_{2} \mathrm{O} /\left(\mathrm{H}_{2} \mathrm{O}+\mathrm{CO}_{2}\right)\right]$ in $\mathrm{mol} \%$. The solidus curves are based on the observation in our charges and are well constrained close to $\mathrm{H}_{2} \mathrm{O}$ saturation; at low $\mathrm{H}_{2} \mathrm{O}_{\text {melt }}$ (and $\mathrm{XH}_{2} \mathrm{O}$ ), they are estimated to be close to the haplogranite solidus of Holtz et al. (2001) and Johannes and Holtz (1990) and close to solidus in other granite crystallization experiments (e.g., Dall'Agnol et al., 1999;

Klimm et al., 2003, 2008). Mineral abbreviations are as follows: Ilm: ilmenite; Mag: magnetite; Cpx: clinopyroxene; Opx: orthopyroxene (low- Ca pyroxene); Amp: amphibole; Bt: biotite; Pl: plagioclase; Kfs: K-feldspar; Qtz: quartz. Redox conditions ( NNO-1.3) are average values; $\mathrm{fO}_{2}$ at $\mathrm{CO}_{2}$-rich crystallization conditions is significantly lower (Table S4).

saturation and the inferred solidus curves. Ilm is present in all charges. Mag has been observed at $800^{\circ} \mathrm{C}$ and $850^{\circ} \mathrm{C}$ in $\mathrm{H}_{2} \mathrm{O}$-rich charges, where it coexists with Ilm.

Crystallization at $300 \mathrm{MPa}$ produces phase relations similar to those determined at $200 \mathrm{MPa}$ (Figure $3 \mathrm{~b}$ versus 3a). Cpx formed in all but four charges (at 800 and $750{ }^{\circ} \mathrm{C}$ and $\mathrm{H}_{2} \mathrm{O}_{\text {melt }}>\sim 7 \mathrm{wt} \%$ ). Lpx stability is limited to $>800^{\circ} \mathrm{C}$ at $\mathrm{H}_{2} \mathrm{O}$ saturation and to $>\sim 750^{\circ} \mathrm{C}$ at $\mathrm{H}_{2} \mathrm{O}_{\text {melt }}<5 \mathrm{wt} \%$. Amp and Bt are likely stable at $>800^{\circ} \mathrm{C}$ according to the experiments performed at $200 \mathrm{MPa}$, but their maximum thermal stability fields were not determined. When compared with the stability at $200 \mathrm{MPa}$, Amp also requires high melt $\mathrm{H}_{2} \mathrm{O}$ (> 6 wt \%) for crystallization, but extends to a significantly lower temperature, i.e., at least to $\sim 675{ }^{\circ} \mathrm{C}$ (instead of $\sim 750^{\circ} \mathrm{C}$ ). Amp is thus stable at near-solidus conditions, but it was not detected in our charges crystallized 
at $660{ }^{\circ} \mathrm{C}$ and $\mathrm{H}_{2} \mathrm{O}$ saturation. As at $200 \mathrm{MPa}, \mathrm{Pl}$ crystallization at $\mathrm{H}_{2} \mathrm{O}$ saturation occurs after Amp (at $<800$ $\left.{ }^{\circ} \mathrm{C}\right)$. Qtz and Kfs appear at yet lower temperatures. Kfs crystallizes before Qtz at low $\mathrm{H}_{2} \mathrm{O}_{\text {melt }}$, unlike at 200 $\mathrm{MPa}$ where Qtz always crystallizes first relative to Kfs. Ttn was detected in some charges at $\sim 700^{\circ} \mathrm{C}$ and at $\sim 800^{\circ} \mathrm{C}$ crystallized at oxidizing conditions, while charges crystallized at reducing conditions showed no Ttn. 4.1.2. Intermediate Phase 2 Biotite-Amphibole Granite At $200 \mathrm{MPa}$, Amp did not crystallize from the Phase 2 composition (Figure 3c) (sample QTL14A, 68 wt \% $\mathrm{SiO}_{2}$ ). Ilm and Lpx are the liquidus phases, while Mag was not observed. Cpx appears at $900^{\circ} \mathrm{C}$ and at $\mathrm{H}_{2} \mathrm{O}_{\text {melt }}>5.5 \mathrm{wt} \%$. Bt crystallizes at $<900^{\circ} \mathrm{C}$ displaying a stability field similar to that for the Phase 1 composition (Figure 3c versus 3a). Compared to the Phase 1 composition, the Pl stability field is depressed to slightly lower temperature, that is, occurring at $\sim 850{ }^{\circ} \mathrm{C}$ at $\sim 4 \mathrm{wt} \% \mathrm{H}_{2} \mathrm{O}_{\text {melt }}$ and below $800{ }^{\circ} \mathrm{C}$ at $\mathrm{H}_{2} \mathrm{O}$ saturation. The stability fields of Kfs and Qtz are slightly larger than those determined for the Phase 1 composition. Crystallization at $300 \mathrm{MPa}$ yields results similar to those at $200 \mathrm{MPa}$, with one key exception: Amp crystallizes at $\sim 750{ }^{\circ} \mathrm{C}$ at $\mathrm{H}_{2} \mathrm{O}$ saturation (Figure 3d). Ttn was observed in oxidizing experiments at 700 and $800{ }^{\circ} \mathrm{C}$ and in some reducing experiments at 660 and $700{ }^{\circ} \mathrm{C}$ (Table S4).

\subsubsection{Evolved Phase 2 Biotite \pm Amphibole Granite}

At $200 \mathrm{MPa}$, the evolved Phase 2 biotite \pm amphibole granite (sample QTL13, 71 wt \% $\mathrm{SiO}_{2}$ ), crystallizes essentially the same mineral assemblage as the intermediate Phase 2 composition, that is, Ilm, Lpx, Cpx, Pl, Kfs, Qtz, Ttn, only lacking Mag. The phase relationships closely compare to those determined for the intermediate Phase 2 composition (Figure 3e versus 3c), except that the stability fields for Lpx and Bt differ. Lpx is no longer a near-liquidus phase, it crystallizes below $900{ }^{\circ} \mathrm{C}$ and at $\mathrm{H}_{2} \mathrm{O}_{\text {melt }}$ of $<5$ wt $\%$. Bt stability becomes sensitive to melt water content. At $\mathrm{H}_{2} \mathrm{O}_{\text {melt }}$ of $\sim 2-3 \mathrm{wt} \%$, it crystallizes at $<800{ }^{\circ} \mathrm{C}$, while it appears below $850{ }^{\circ} \mathrm{C}$ at $\mathrm{H}_{2} \mathrm{O}$ saturation. Ttn is also present at 660 and $700{ }^{\circ} \mathrm{C}(300$ and $400 \mathrm{MPa})$, which is similar to its stability in the intermediate Phase 2 composition. The phase relations determined at $300 \mathrm{MPa}$ do not significantly differ from those at $200 \mathrm{MPa}$ (Figure 3f).

\subsubsection{Phase Relations Summary}

Apart from Bt, which displays similar stability fields for all three compositions, the variation in saturation curves described above shows that even relatively minor compositional variations critically affect phase relationships (e.g., as previously observed for other compositions, e.g., by Cadoux et al., 2014 or Scaillet et al., 2016). The most notable variation is observed for Amp and Lpx. For both phases, the stability fields progressively shrink with evolving bulk-rock composition. Another notable feature is the peritectic relationship between Cpx and Amp; that is, Cpx is absent in low-temperature and $\mathrm{H}_{2} \mathrm{O}$-saturated charges whenever Amp is stable. Our results show also that increasing pressure enlarges the stability field of Amp toward lower temperature, a reflection of the increase in $\mathrm{H}_{2} \mathrm{O}$ solubility in the melt. Yet, the low-temperature limb of the Amp field does not straddle the solidus at $300 \mathrm{MPa}$ in our Phase 1 experiments, while it is close to it, and Amp did not crystallize near solidus from our Phase 2 experiments. This could indicate (1) that Amp was indeed not a stable solidus phase in the natural system; (2) that Amp crystallized in our $\mathrm{H}_{2} \mathrm{O}$-rich, solidus experiments, but that it remained undetected owing to its small crystal size; (3) that other phases formed metastably instead of Amp; (4) that the natural magmas crystallized at more reducing conditions than our experiments; or (5) that Amp in the natural system crystallized at still higher pressure.

The interpretation that Amp was not stable at the solidus in the natural system is rebutted, as it should show significant replacement by biotite (e.g., cf. Zhao et al., 2017, 2018), which is not the case. That Amp crystallized at solidus conditions in our experiments, yet that it remained undetected is possible, while we note that we have thoroughly searched for it in multiple sessions on the scanning electron microscope and the electron microprobe. That other phases (e.g., Cpx or Ttn) metastably formed instead of Amp (owing to Amp nucleation problems) is difficult to rule out. Our main point is that Amp crystallized at least at near-solidus conditions and we thus argue that the conditions of our experiments closely approached those of the natural system. Dall'Agnol et al. (1999) have shown that low $\mathrm{fO}_{2}$ significantly displaces the stability field of Amp downward in a $T-\mathrm{H}_{2} \mathrm{O}_{\text {melt }}$ projection, where Amp replaces $\mathrm{Cpx}$ at near solidus and $\mathrm{H}_{2} \mathrm{O}$-rich conditions, while our and several previous studies have shown that Amp stability also increases with increasing pressure. We highlight here that Amp was not stable in our experiment performed at $660{ }^{\circ} \mathrm{C}, 360 \mathrm{MPa}$, NNO -1.0 and $\mathrm{H}_{2} \mathrm{O}$ saturation, while it crystallized in the experiment at $700{ }^{\circ} \mathrm{C}, 400 \mathrm{MPa}, \mathrm{NNO} \sim-1.4$ and $\mathrm{H}_{2} \mathrm{O}$ saturation, and thus at only slightly higher pressure and lower $\mathrm{fO}_{2}$ (Table S4). We therefore posit that Amp crystallized from the Phase 1 and the Phase 2 compositions at the solidus at conditions that differed 

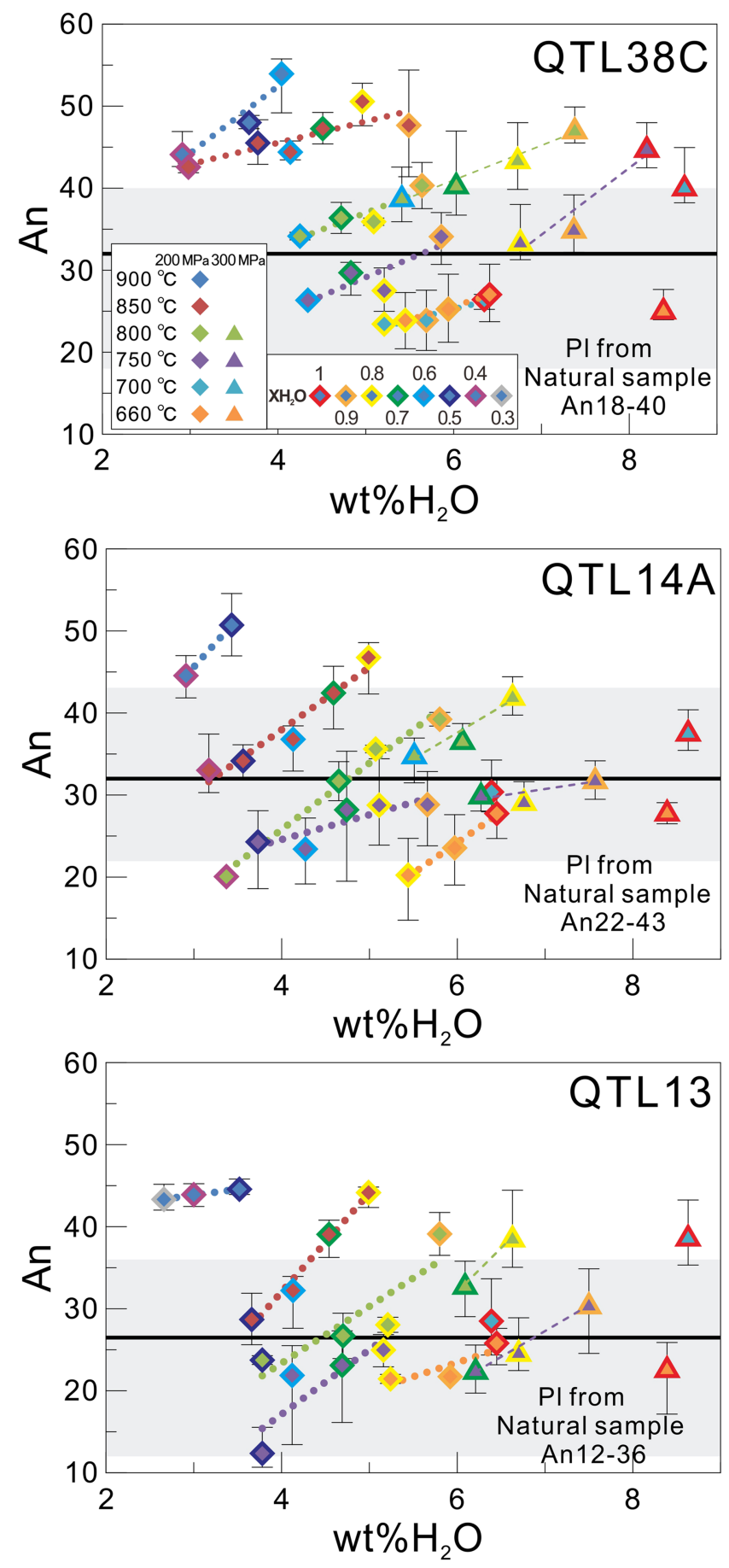

Figure 4. Anorthite (An) content of plagioclase plotted as a function of melt $\mathrm{H}_{2} \mathrm{O}$ content and for different experimental temperatures and pressures. The gray area highlights the core-rim compositional range of natural plagioclase crystals in the three samples (top: QTL38C, middle: QTL14A, bottom: QTL13) for comparison. The bold black line is the average An value of the natural plagioclase crystals. Vertical bars highlight the detected compositional variation. only slightly from those of our experiments, and we have therefore tentatively indicated Amp stability in Figures $3 \mathrm{~b}$ and $3 \mathrm{f}$. If Amp in the natural system crystallized at a pressure slightly higher than $\sim 360 \mathrm{MPa}$ and/or lower $f_{2}$ than $\mathrm{NNO} \sim-1.0$ is discussed further below using mineral compositional data (in section 4.2 and in section 5.2). From a comparison with other A-type granites (Table S3 and Figure S1), we highlight in addition that low magma $\mathrm{Al}_{2} \mathrm{O}_{3}$ contents increase $\mathrm{Cpx}$ stability fields at the expense of Amp and $\mathrm{Pl}$, while elevated $\mathrm{K}_{2} \mathrm{O}$ enlarges the stability fields of $\mathrm{Bt}$ at the expense of Amp, shrinking the Amp field toward high $\mathrm{H}_{2} \mathrm{O}_{\text {melt }}$. Comparison with available data (Bogaerts et al., 2006; Dall'Agnol et al., 1999; Klimm et al., 2003) indicates that in $\mathrm{SiO}_{2}$-rich ( $>70$ wt \%) magmas stored in shallow crust ( $\leq 200-300 \mathrm{MPa})$, Amp crystallization is inhibited when the bulk $\mathrm{K}_{2} \mathrm{O}$ content is $>4.5 \mathrm{wt} \%$.

\subsection{Phase Compositions \\ 4.2.1. Plagioclase}

The Pl An content decreases from the most mafic to the most felsic composition, that is, from $\sim$ An54-23\% to $\sim$ An51-20\% to $\sim$ An $45-12 \%$, respectively. For each composition, the An content of $\mathrm{Pl}$ increases systematically with temperature and $\mathrm{H}_{2} \mathrm{O}_{\text {melt }}$ (and therefore with pressure as pressure increases $\mathrm{H}_{2} \mathrm{O}$ melt solubility) as observed in previous studies (e.g., Bogaerts et al., 2006; Dall'Agnol et al., 1999; Klimm et al., 2003; Klimm et al., 2008; Scaillet \& Evans, 1999; Figure 4). The Or content of $\mathrm{Pl}$, in contrast, increases when both temperature and $\mathrm{H}_{2} \mathrm{O}_{\text {melt }}$ decrease (Table S5). The An content of $\mathrm{Pl}$ formed at oxidizing conditions is higher compared to $\mathrm{Pl}$ crystallized at reducing conditions (e.g., with a maximum difference of $\sim$ An15 in our experiments; Table S5). A similar finding was reported by Dall'Agnol et al. (1999).

\subsubsection{Pyroxenes}

Both Lpx and Cpx are observed in our crystallization experiments at most conditions, including the near-solidus experiments, yet they are absent from the natural samples. Cpx has $<9$ wt $\% \mathrm{Al}_{2} \mathrm{O}_{3}$ and $<3$ wt $\% \mathrm{Na}_{2} \mathrm{O}$. Diopside formed at 850 and $800{ }^{\circ} \mathrm{C}$, at $\mathrm{H}_{2} \mathrm{O}$ saturation and either reducing conditions $(\sim \mathrm{NNO}-1.3)$ or oxidizing conditions $(\sim \mathrm{NNO}+2.4)$. Hedenbergite crystallized in experiments at $<800{ }^{\circ} \mathrm{C}$ and at reducing conditions ( NNO-1.3). At $900-800{ }^{\circ} \mathrm{C}$ and at $\mathrm{H}_{2} \mathrm{O}$-undersaturated conditions, $\mathrm{Cpx}$ has augite composition. Its Wo content increases with increasing $\mathrm{XH}_{2} \mathrm{O}$, while its Fs content increases with decreasing temperature. Lpx is mostly pigeonite, except for crystals in two charges $\left(900{ }^{\circ} \mathrm{C}\right.$, $\mathrm{XH}_{2} \mathrm{O}=0.9 ; 850^{\circ} \mathrm{C}, \mathrm{XH}_{2} \mathrm{O}=1$ ), which are clinoenstatite and clinoferrosilite. Lpx has $<7$ wt $\% \mathrm{Al}_{2} \mathrm{O}_{3}$ and $<1$ wt $\% \mathrm{Na}_{2} \mathrm{O}$. Its Wo content increases with decreasing $\mathrm{XH}_{2} \mathrm{O}$ (contrary to $\mathrm{Cpx}$ ), while its Fs content increases with decreasing temperature (Figure 5; Table S6).

\subsubsection{Amphibole}

Amp produced in our experiments is always calcic ( $>1.5 \mathrm{apfu}(\mathrm{Ca}, \mathrm{Na}) ; \mathrm{Na}$ $<0.5$ apfu). According to Leake et al. $(1997,2003)$, it classifies as hornblende, pargasite, magnesiohastingsite, ferropargasite, ferroedenite, or edenite. Its $\mathrm{TiO}_{2}$ content ranges between $\sim 0.8$ and $\sim 2.3 \mathrm{wt} \%$. $\mathrm{Al}^{\text {tot }}$ shows a broad positive correlation with pressure, but there is not a simple linear relationship. For instance, at $\sim \mathrm{NNO}+2.4$ and $800{ }^{\circ} \mathrm{C}$, the $\mathrm{Al}^{\text {tot }}$ of Amp crystallized from the Phase 1 composition at 200, 360, and $700 \mathrm{MPa}$, is $1.48,1.70$, and $1.65 \mathrm{apfu}$, respectively. The Amp $X_{\mathrm{Fe}}[\mathrm{Fe} /(\mathrm{Fe}+\mathrm{Mg})]$ content increases with temperature and decreases with oxygen fugacity. $X_{\mathrm{Fe}}$ also increases slightly with decreasing $\mathrm{H}_{2} \mathrm{O}_{\text {melt }}$ (Figure 6), but it does not vary obviously with pressure (at $\sim \mathrm{NNO}+2.4$ and 800 


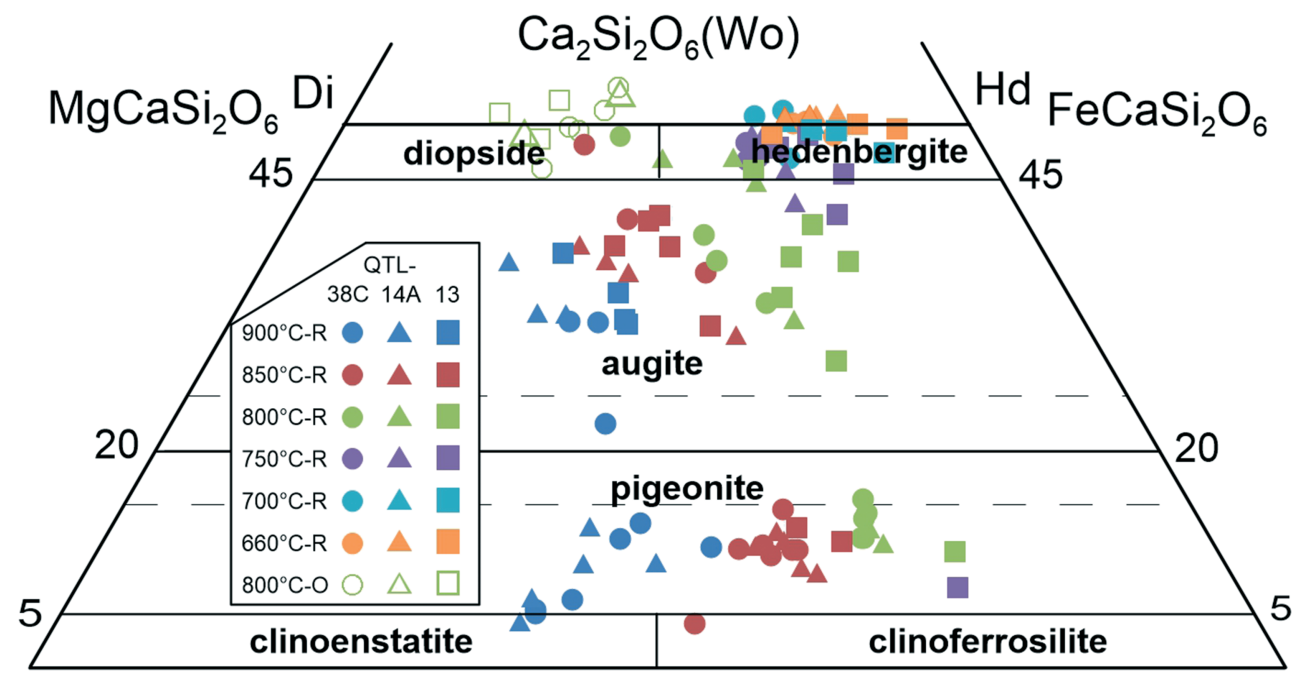

En

Fs $\mathrm{Mg}_{2} \mathrm{Si}_{2} \mathrm{O}_{6}$

Figure 5. Composition of experimental pyroxene from the three samples crystallized at different temperatures (see inset). Solid symbols identify pyroxene compositions from reducing ( NNO-1.3) experiments; open symbols identify pyroxenes from oxidizing ( NNO+2.4) experiments. Circles, triangles, and squares are for pyroxene from QTL38C (Phase 1); QTL14A (Phase 2); QTL13 (Phase 2), respectively.

${ }^{\circ} \mathrm{C}$, the $X_{\mathrm{Fe}}[\mathrm{Fe} /(\mathrm{Fe}+\mathrm{Mg})]$ values of Amp crystallized at 200, 300, and $700 \mathrm{MPa}$ are $0.21,0.21$, and 0.18 , respectively). Amp produced from Phases 1 and 2 compositions has similar compositions in terms of $X_{\mathrm{Fe}}$. At $300 \mathrm{MPa}$, $750{ }^{\circ} \mathrm{C}$, and $\sim \mathrm{NNO}-1.3$, for instance, $X_{\mathrm{Fe}}$ of Amp is 0.65 in both Phases 1 and 2 experiments. Therefore, pressure and bulk compositional effects on Amp $X_{\mathrm{Fe}}$ are very small (Table S7). Amp F contents in both experimental and natural crystals are moderately low ( $\sim 0.35$ and $\sim 0.49$ wt $\%$ on average), while the experimental Amp crystals have lower $\mathrm{Cl}$ contents $(<0.02 \mathrm{wt} \%)$ than the natural crystals $(\sim 0.26 \mathrm{wt} \%$ on average).

\subsubsection{Biotite}

Bt grain size is small in all charges $(<10 \mu \mathrm{m})$ which, together with its high aspect ratio, made glass contamination unavoidable during EMP analysis. Bt analyses with high degrees of glass contamination (i.e., with $\mathrm{K}_{2} \mathrm{O}<6$ wt $\%$ and $>10 \%$ contamination) were not considered. All other data reported are original; that is, they are the uncorrected, measured compositions. Bt contains $\sim 1-5 \mathrm{wt} \% \mathrm{TiO}_{2}$. The crystals have $X_{\mathrm{Fe}}$ values in the range of $0.42-0.75$ (Table $\mathrm{S} 8$ ), where $X_{\mathrm{Fe}}$ increases with decreasing temperature and $\mathrm{H}_{2} \mathrm{O}_{\text {melt }}$, the trend being similar to that of Amp. Similar to Amp, Bt crystallized from all three compositions (which have different $\mathrm{Fe}_{\text {tot }}$ contents) and at the same P-T- $f \mathrm{O}_{2}$ conditions has comparable $X_{\mathrm{Fe}}$ (Figure 7). Bt shows, like Amp, moderately high $\mathrm{F}$ contents in our experimental charges and the natural samples $(\sim 0.48$ and $\sim 0.61$ wt $\%$ on average, respectively) and lower $\mathrm{Cl}$ contents in experimental compared to natural crystals $(\sim 0.01$ and $\sim 0.34$ wt $\%$ on average, respectively). Melt $\mathrm{F}$ and $\mathrm{Cl}$ contents calculated using the partition coefficients of Icenhower and London (1997) and the natural Bt compositions are $\sim 0.17$ and $\sim 0.12 \mathrm{wt} \%$, respectively.

\subsubsection{Fe-Ti Oxides}

Due to their small grain size, good quality analyses of Fe-Ti oxides were difficult to obtain. At reducing conditions, Ilm has relatively high $\mathrm{FeO}$ and low $\mathrm{Fe}_{2} \mathrm{O}_{3}$ contents (calculated at $\sim 30-44$ wt $\%$ and $\sim 1-10$ wt $\%$, respectively), with ilmenite contents of 86-99 mol \%. Ilmenite content increases with temperature and decreases with $\mathrm{H}_{2} \mathrm{O}_{\text {melt }}$. The $\mathrm{MnO}$ content of all experimental $\mathrm{Ilm}$ is $<2.2 \mathrm{wt} \%$, increasing when temperature decreases, while the $\mathrm{MgO}$ content increases with temperature, up to a maximum of $\sim 3.8 \mathrm{wt} \%$. Mag formed at $\sim \mathrm{NNO}+2.4$ has ulvöspinel (Usp) contents in the range of $21-37 \mathrm{~mol} \%$. At $800{ }^{\circ} \mathrm{C}$, water saturation, and NNO -1.3, Mag in Phase 1 run products has a higher Usp content (41 mol \%) compared to run products formed at oxidizing conditions (37 mol \%). The bulk rock composition also affects Mag composition. For instance, at $200 \mathrm{MPa}, 800{ }^{\circ} \mathrm{C}$, water saturation and $\sim \mathrm{NNO}+2.4$, the Usp content decreases from Phase 1 to Phase 3 compositions from 37 to $24 \mathrm{~mol} \%$ (Table S9). 


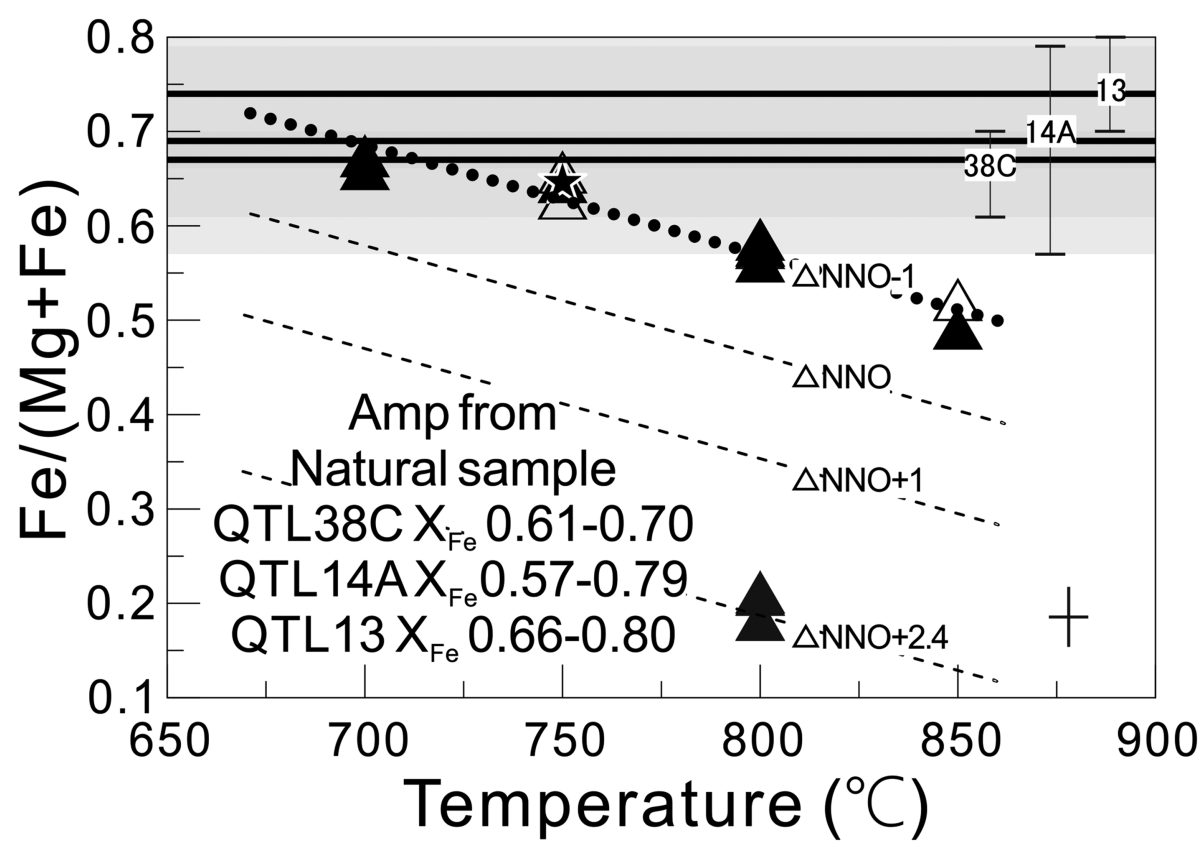

Figure 6. Composition of experimental amphibole at water saturation $(\mathbf{\Lambda})$ and below water saturation $(\triangle)$ plotted as a function of temperature with compositions of natural amphibole (shaded area). Triangles represent the experimental amphibole crystallized from Phase 1 composition (QTL-38) while the solid star represents those from the Phase 2 composition (QTL14A). The gray area marks the range of $X_{\mathrm{Fe}}=\mathrm{Fe} /(\mathrm{Mg}+\mathrm{Fe})$ of natural amphiboles from the three samples studied in detail, whereas the bold black lines are the average $\mathrm{Fe} /(\mathrm{Mg}+\mathrm{Fe})$ values. The horizontal bar is the maximum uncertainty of the experimental temperature; the vertical bar is the maximum uncertainty (maximum standard deviation for all charges) of $\mathrm{Fe} /(\mathrm{Mg}+\mathrm{Fe})$. Note that the inferred $f_{\mathrm{O}_{2}}$ conditions (e.g., NNO-1) are for crystallization in charges with $\mathrm{XH}_{2} \mathrm{O} \geq 0.8$ and thus above reported average conditions (e.g., $\sim \mathrm{NNO}-1.3$ ).

\subsubsection{Titanite}

Ttn was observed in all three compositions but only at water-saturated conditions. At oxidizing conditions (NNO +2.4), Ttn crystallized at $800{ }^{\circ} \mathrm{C}(700 \mathrm{MPa})$ and $700{ }^{\circ} \mathrm{C}(200 \mathrm{MPa})$ in Phase 1 and intermediate Phase 2 compositions. At reducing conditions (NNO -1.3), Ttn crystallized only at $\leq 700{ }^{\circ} \mathrm{C}$ and at $\geq 300$ MPa. Ttn has $\sim 1.7-5$ wt $\% \mathrm{Al}_{2} \mathrm{O}_{3}, \sim 27-32$ wt $\% \mathrm{TiO}_{2}$, and $\sim 22-26$ wt $\% \mathrm{CaO}$.

\subsubsection{Glass}

Except for some crystal-rich charges at low $\mathrm{H}_{2} \mathrm{O}_{\text {melt }}$, the compositions of residual glasses were successfully analyzed by EMP. All glasses analyzed are homogeneous within the error of the method (see details in Table S10). The residual glasses from our three series of experiments show closely comparable and coherent compositional trends, though they differ in absolute values. Glasses become more evolved as temperature and $\mathrm{H}_{2} \mathrm{O}_{\text {melt }}$ decrease, being predominantly metaluminous. Glass $\mathrm{Al}_{2} \mathrm{O}_{3}$ content significantly varies as a function of $\mathrm{Pl}$ abundance. In Pl-free charges at $200 \mathrm{MPa}, \mathrm{Al}_{2} \mathrm{O}_{3}$ shows minor variation ( 14.8-15.5 wt \% for Phase 1 composition (QTL-38); 14-15 wt \% for intermediate Phase 2 composition (QTL-14); 13.814.3 wt \% for evolved Phase 2 composition (QTL13)), while it decreases significantly once Pl crystallizes (Figures 8a-8c). At temperatures higher than $700{ }^{\circ} \mathrm{C}$, the fact that the $\mathrm{K}_{2} \mathrm{O}$ content increases with decreasing $\mathrm{H}_{2} \mathrm{O}_{\text {melt }}$ reflects that at low $\mathrm{H}_{2} \mathrm{O}_{\text {melt }} \mathrm{Bt}$ crystallizes in relatively low proportion (Figures 8d-8f). Similarly, $\mathrm{CaO}$ and $\mathrm{FeO}$ (and $\mathrm{TiO}_{2}$, not shown) contents continuously decrease with increasing degrees of crystallization, reflecting increasing precipitation of ferro-magnesian phases (Figures 8g-81).

\section{Discussion}

Below, we first assess the approach to equilibrium in our experiments. We then constrain the intensive parameters of crystallization for the Qitianling granitic magmas and the processes that have governed the geochemical evolution of the pluton. 

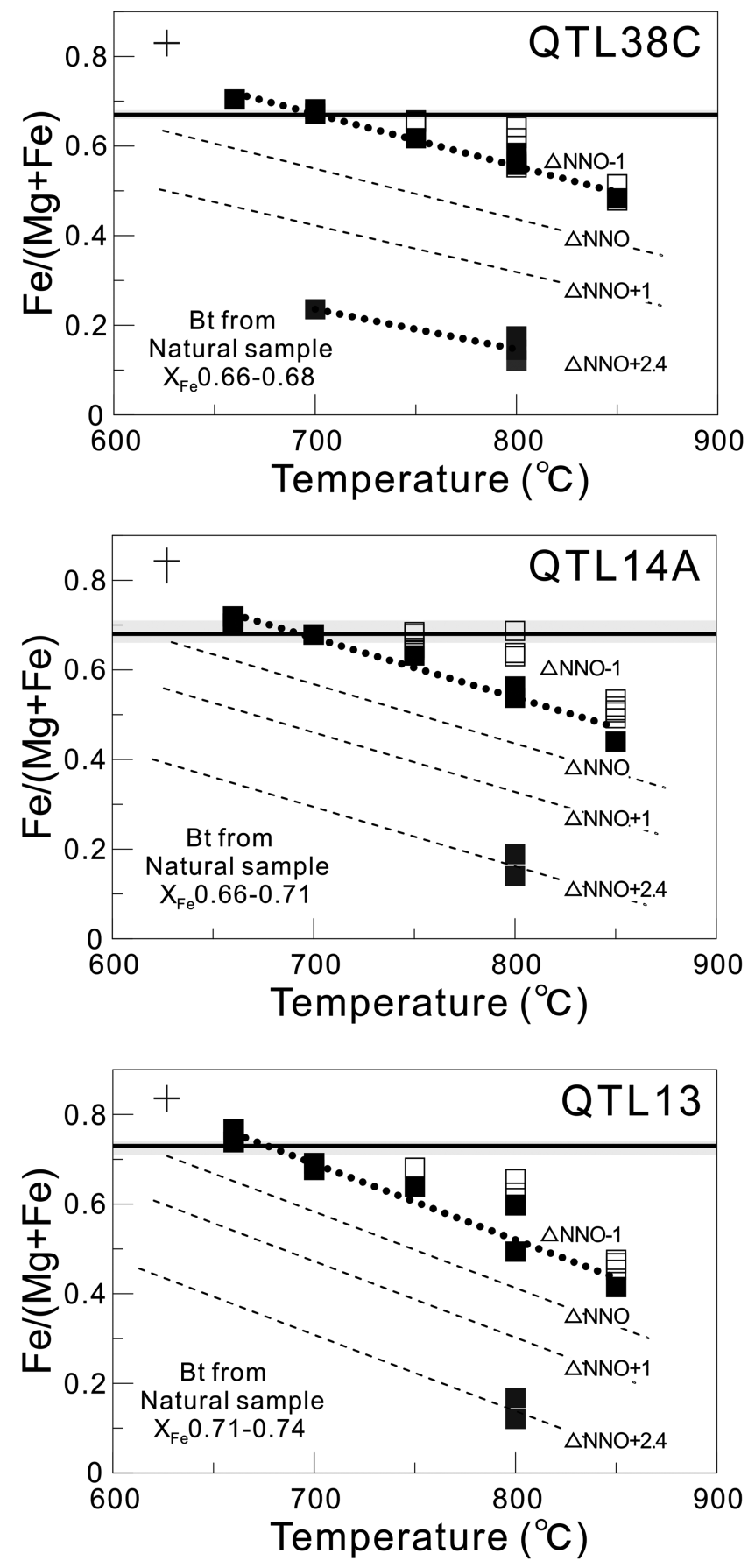

Figure 7. Composition of experimental biotite at water saturation $(\square)$ and below water saturation ( $\square$ ) plotted as a function of temperature for Phase 1 (QTL38C) and Phase 2 (QTL14A and QTL13). Compositional range of the natural biotite is shaded in gray, whereas the bold black lines are the average $X_{\mathrm{Fe}}=\mathrm{Fe} /(\mathrm{Mg}+\mathrm{Fe})$ values. The horizontal bar is the maximum uncertainty of the experimental temperatures; the vertical bar is the maximum uncertainty (maximum standard deviation for all charges) of $\mathrm{Fe} /(\mathrm{Mg}+\mathrm{Fe})$. Note that the inferred $f_{2} \mathrm{O}_{2}$ conditions (e.g., NNO-1) are for crystallization in charges with $\mathrm{XH}_{2} \mathrm{O} \geq 0.8$ and thus above reported average conditions (e.g., $\sim \mathrm{NNO}-1.3$ ).

\subsection{Attainment of Equilibrium}

This study has used a standard procedure of crystallization which has been shown to favor the attainment of equilibrium conditions in experiments on granitic compositions (e.g., Clemens \& Wall, 1981; Clemens et al., 1986; Klimm et al., 2003; Pichavant, 1987; Pichavant et al., 2007; Scaillet et al., 1995). The textures and compositional attributes of our run products do not depart from those reported in previous studies on similar starting materials. The main features are that (1) the phases are homogeneously distributed, (2) the composition of minerals and glass in single charges is also homogeneous within the uncertainty of the method, (3) phase assemblages and compositions vary systematically with experimental parameters, and (4) mineral textures are also homogeneous, including those in highly crystallized charges. As outlined below, the experimental results reproduce the main petrological characteristics of the rocks selected for the experiments, showing that the investigated $\mathrm{P}-\mathrm{T}-\mathrm{H}_{2} \mathrm{O}_{\text {melt }}-\mathrm{fO}_{2}$ space has captured the natural framework of granitic magma evolution.

\subsection{Crystallization Conditions of the Qitianling Granite (P-T- $\mathrm{H}_{2} \mathrm{O}_{\text {melt }}-\mathrm{fO}_{2}$ ) \\ 5.2.1. Pressure}

At $200 \mathrm{MPa}$, only the Phase 1 composition produced Amp, but not the Phase 2 compositions, which is in contrast with the occurrence of Amp in the natural Phase 2 rocks. Amp is moreover not a near-solidus phase in the $200-\mathrm{MPa}$ experiments (it only crystallized at $>700{ }^{\circ} \mathrm{C}$ ), yet it is inferred to have been a stable solidus phase in the natural system as Amp crystals are largely unzoned and as they do not show evidence for breakdown to either Bt or Ttn. At $300 \mathrm{MPa}$, in contrast, Amp is stable in the experiments using the Phase 1 and the intermediate Phase 2 compositions (QTL38C and QTL14A), with a stability field extending to within $<50{ }^{\circ} \mathrm{C}$ of the solidus. Amp is still absent from the crystallization products of the evolved Phase 2 composition though, further suggesting that the crystallization conditions of the natural system were closely approached but not perfectly matched.

The average $\mathrm{Al}_{\text {tot }}$ content of the natural Amp in Phase 1 and Phase 2 granites is $1.4-1.5$ (1.43 on average), that is, equivalent to the $\mathrm{Al}$ content of the experimental Amp produced at $700{ }^{\circ} \mathrm{C}$ and $300 \mathrm{MPa}\left(\mathrm{Al}_{\text {tot }}=1.43\right)$, yet significantly lower than the $\mathrm{Al}$ content of Amp produced at $700{ }^{\circ} \mathrm{C}$ and $400 \mathrm{MPa}\left(\mathrm{Al}_{\text {tot }}=1.77\right)$. Ttn, which is characteristic for the natural samples, was also observed only at $\geq 300 \mathrm{MPa}$ at reducing conditions. In combination, we take this to conclude that the Qitianling magmas crystallized at $>300$ and $<350 \mathrm{MPa}$, and thus at slightly higher pressure than investigated in our experiments at $\mathrm{H}_{2} \mathrm{O}$ saturation. This pressure range is in good agreement with that calculated for the natural Amp compositions and various amphibole barometers (which yield a crystallization pressure of $\sim 360 \pm 90 \mathrm{MPa}$, Zhao et al., 2005; Table S7), and we thus conclude that the existing amphibole barometers yield reliable estimates for ferroan A-type granites like those of the Qitianling pluton.

The inferred emplacement pressure is higher than that typical for evolved magmatic reservoirs in arcs or anorogenic settings ( $\leq 100-250 \mathrm{MPa}$, e.g., Andújar \& Scaillet, 2012; Clemens et al., 1986; Klimm et al., 2003; Mahood, 1984; Scaillet et al., 1998; Scaillet \& Macdonald, 2001) but compares to that of crustal-derived magmas that have formed and evolved within thick crust (typically at 300-500 MPa; e.g., cf. Bogaerts et 

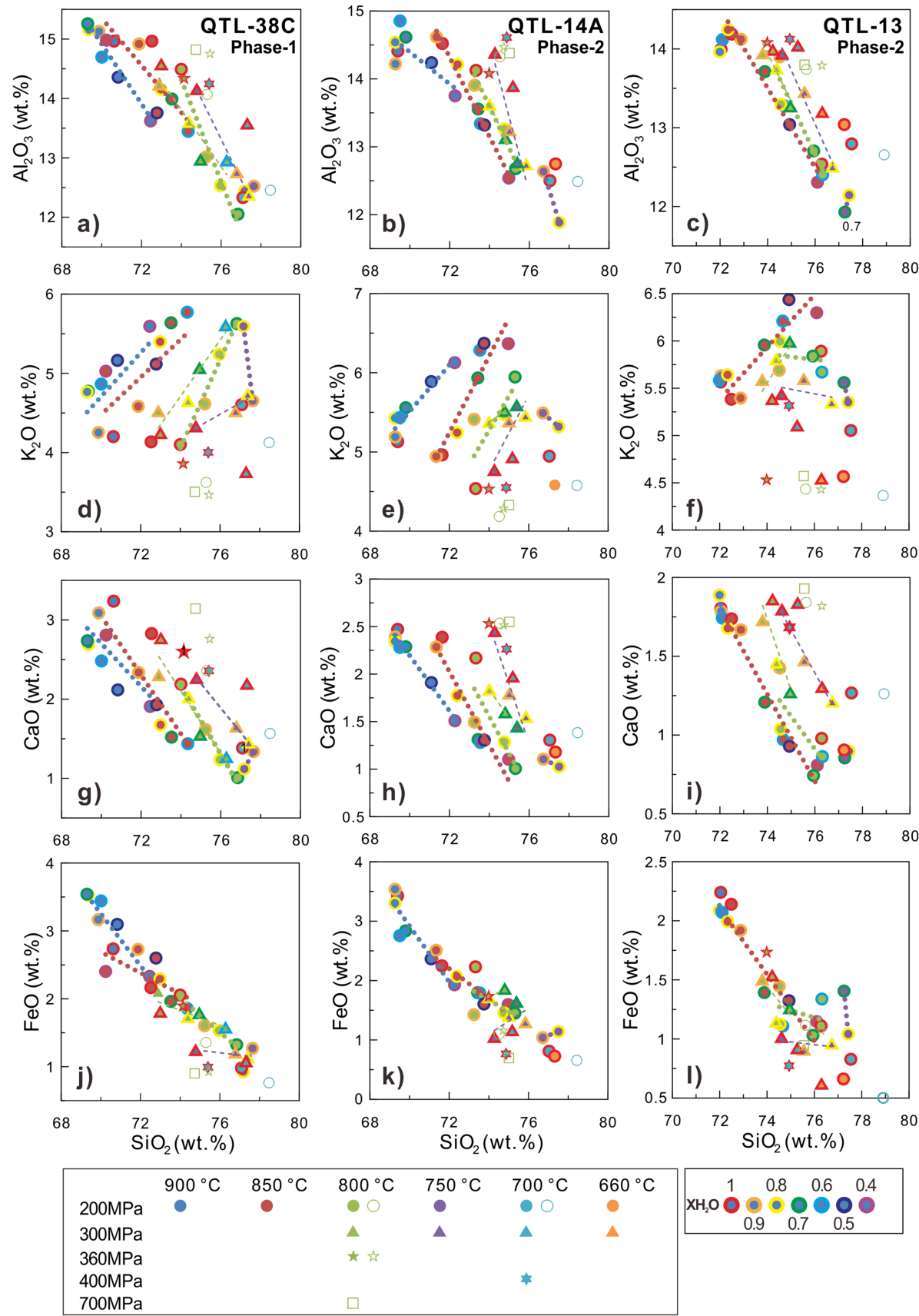

Figure 8. Variation of residual glass compositions for Phase 1 (QTL38C, left column) and Phase 2 (QTL14A, middle column; QTL13, right column) samples at different pressure, temperature, oxygen fugacity and melt $\mathrm{H}_{2} \mathrm{O}$ contents. Solid symbols and open symbols represent glasses from reducing ( NNO-1.3) and oxidizing charges $\left(\sim \mathrm{NNO}+2.4\right.$ at $800{ }^{\circ} \mathrm{C}$ and $\sim \mathrm{NNO}+2.8$ at $700^{\circ} \mathrm{C}$ ), respectively.

al., 2006; Chaussard \& Amelung, 2014; Dall'Agnol et al., 1999; Scaillet et al., 1995; Scaillet et al., 2016). The exposed rocks of the Qitianling pluton represent the near-roof section of the up to $\sim 5 \mathrm{~km}$ thick, lopolith-like intrusion (Liu et al., 2018), indicating pluton emplacement at midcrustal depth of $12-13$ to $17-18 \mathrm{~km}$ (for an average crustal density of $2,600 \mathrm{~kg} / \mathrm{m}^{3}$ ) and at pressures of $>300$ to $\sim 450 \mathrm{MPa}$.

\subsubsection{Temperature}

Ilm or Ilm $+\mathrm{Cpx}$ are present at $900{ }^{\circ} \mathrm{C}$, the maximum temperature that we have explored in our experiments. This suggests that the Qitianling magmas formed at $\sim 900{ }^{\circ} \mathrm{C}$. The zircon saturation temperatures of the 
Qitianling granites are significantly lower $\left(\sim 715-875^{\circ} \mathrm{C}, \sim 815^{\circ} \mathrm{C}\right.$ on average), implying that zircon saturated and crystallized late and that little to no zircon was inherited from the source, which is consistent with the magmatic zoning patterns and the scarcity of old, inherited zircon cores in the granites (e.g., Zhu et al., 2009). $\mathrm{Pl}$ of the natural samples has $\sim$ An43 to $\sim$ An12 composition. The crystal cores have predominantly $\sim$ An30-40, $\sim$ An30-43, and $\sim$ An25-40 composition in the Phase 1, intermediate Phase 2, and evolved Phase 2 samples, respectively, which we interpret to have crystallized near the solidus. Only the outer $<10 \mu \mathrm{m}$ of the crystals or altered crystal zones locally show An-poor composition ( An02-20). For crystallization under $\mathrm{H}_{2} \mathrm{O}$-rich conditions (as implied by Amp occurrence), and at a pressure $\geq 300 \mathrm{MPa}$, the An range of the Pl records crystallization at $\leq 700-750{ }^{\circ} \mathrm{C}$ (cf. Figure 4). Low An contents of $<$ An20, which are characteristic for some of the crystal rims and altered zones of the natural crystals are also produced in our experiments, but only for crystallization at low $\mathrm{XH}_{2} \mathrm{O}$ (e.g., $<0.4$ at $800{ }^{\circ} \mathrm{C}$ for QTL14A or $<0.5$ at $750{ }^{\circ} \mathrm{C}$ for QTL13). In combination with the textural relations (i.e., the common association of low-An Pl zones with alteration products), we therefore suggest that the low-An zones formed at subsolidus conditions in reaction with fluids that affected a minor proportion ( $<2-5 \mathrm{vol} \%$ ) of the Phase 1 and Phase 2 granites. The origin of the fluids and their intensive parameters remain unconstrained at present.

The $X_{\mathrm{Fe}}$ of $\sim 0.7$ of the natural Amp in the Phase 1 and Phase 2 granites equally indicates that the magmatic crystals formed or equilibrated at $\leq 700{ }^{\circ} \mathrm{C}$ if crystallization took place at $\mathrm{H}_{2} \mathrm{O}$ saturation and at $\sim \mathrm{NNO}-1 \pm 0.5$ (as discussed further below). The Si content of the natural Amp crystals is, however, slightly lower than that of the crystals formed in our $300 \mathrm{MPa}$ near-solidus experiments ( 6.6 versus $\sim 6.9 \mathrm{apfu}$ ), which we interpret to reflect the slightly higher crystallization pressure of the natural crystals (at $>300$ and $<350 \mathrm{MPa}$ ). At $\sim \mathrm{NNO}$ $-1 \pm 0.5$, the $\mathrm{Bt} X_{\mathrm{Fe}}$ of $\sim 0.7$ records crystallization (and/or reequilibration) at $\sim 650^{\circ} \mathrm{C}$ (Figure 7 ), that is, similar to the compositional record of both Amp and Pl. Evidence for magmatic crystallization at temperatures significantly below $\sim 650{ }^{\circ} \mathrm{C}$ (i.e., at $\sim 450-550{ }^{\circ} \mathrm{C}$ ), which has recently been proposed for some arc-related granite intrusions (Ackerson et al., 2018), is not recorded in Amp or Bt core or rim compositions.

The comparison of natural Amp, Bt, and $\mathrm{Pl}$ compositions with those of our experimental run products highlights that the main mass of the Qitianling minerals records near-solidus conditions at $\sim 650$ and $\leq 660-700{ }^{\circ} \mathrm{C}$. This is in contrast to the amphibole and amphibole-plagioclase crystallization temperatures estimated using the natural mineral compositions and the calibrations of Anderson and Smith (1995) and Putirka (2016), which both yield calculated crystallization temperatures of $\sim 750-800{ }^{\circ} \mathrm{C}$. Anderson and Smith (1995) caution that their calibration should not be applied to Amp crystallized at $<$ NNO with calculated $\mathrm{Fe}^{3+} /\left(\mathrm{Fe}^{3+}+\mathrm{Fe}^{2+}\right)$ of $\sim \leq 0.20-0.25$ (Qitianling's Amp has calculated $\mathrm{Fe}^{3+} /\left(\mathrm{Fe}^{3+}+\mathrm{Fe}^{2+}\right)$ of $\sim 0.10-0.19$ ), and unrealistic estimates should thus have been expected. Putirka (2016) does not suggest any such restrictions for the application of his Amp thermometers (equations 5 and 6), while they were largely calibrated on Amp crystallized at $\sim 750-1100^{\circ} \mathrm{C}$. Our results show that for the Amp compositions and crystallization conditions typical for the Qitianling granites, and likely also for other ferroan (A-type) granites, Amp crystallization temperatures are significantly overestimated using the two sets of thermometers, which should not be employed (Figure S2).

\subsubsection{Melt $\mathrm{H}_{2} \mathrm{O}$ and Other Volatile Contents}

Amp is characteristic for the Phases 1 and 2 Qitianling natural granites. The minimum $\mathrm{H}_{2} \mathrm{O}_{\text {melt }}$ at which Amp stabilized in our crystallization experiments is $\sim 5.5-6.0 \mathrm{wt} \%$ at $850-800{ }^{\circ} \mathrm{C}$ and 200 or $300 \mathrm{MPa}$ for Phase 1 granite, highlighting that the natural magmas must have been $\mathrm{H}_{2} \mathrm{O}$-rich. At $300 \mathrm{MPa}$, the stability of Amp extends to even higher $\mathrm{H}_{2} \mathrm{O}_{\text {melt }}$, that is, $\sim 8 \mathrm{wt} \%$ for the Phase 1 and intermediate Phase 2 compositions (Figure 3), and thus $\mathrm{H}_{2} \mathrm{O}_{\text {melt }}$ at or very near saturation (Figure 3). The composition of the natural $\mathrm{Pl}$ crystals ( An32 for Phase 1 and intermediate Phase 2 and $\sim$ An 27 for the evolved Phase 2 on average) are consistent with crystallization at $\leq 750{ }^{\circ} \mathrm{C}$ under $\mathrm{H}_{2} \mathrm{O}$-rich conditions (i.e., $\mathrm{H}_{2} \mathrm{O}_{\text {melt }} \geq 6.5-8.0$ wt \%; Figure 4). For an inferred crystallization pressure of $\geq 300 \mathrm{MPa}$, we thus construe that the Qitianling magmas last crystallized with $\mathrm{H}_{2} \mathrm{O}_{\text {melt }} \geq 6.5-8.0$ wt $\%$. The initial bulk $\mathrm{H}_{2} \mathrm{O}$ content of the Phase 1 magma can be constrained assuming a closed system crystallization and that water behaves largely in an incompatible manner during magma cooling. Figure 9 shows several possible crystallization paths for the more mafic Phase 1 Qitianling granite, drawn under the closed system assumption, for different bulk water contents. While all paths are able to reproduce the final phase assemblage, in particular the occurrence of Amp, they differ with respect to the temperature of Amp first appearance. It can be seen that Amp early crystallization (above $800{ }^{\circ} \mathrm{C}$ ), as suggested by its texture in the rocks (Figure 2), occurs for bulk $\mathrm{H}_{2} \mathrm{O}$ contents higher than 4 wt $\%$. 

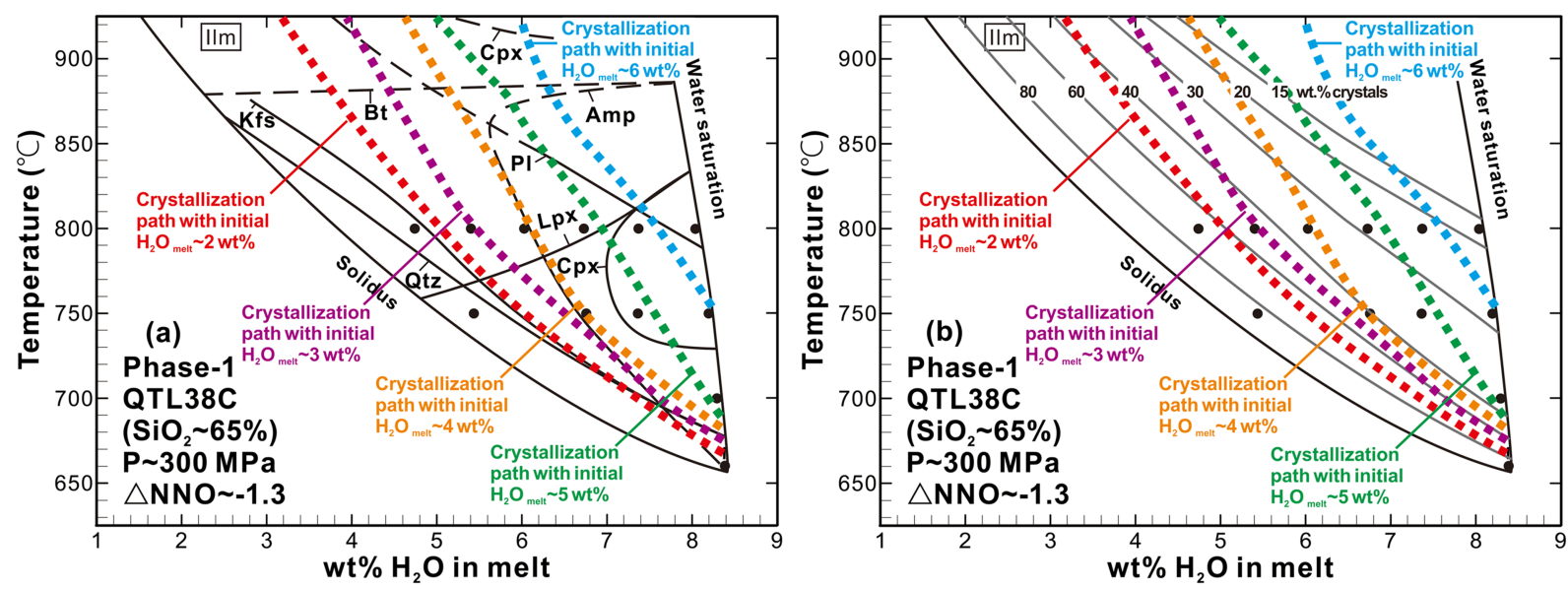

Figure 9. Possible T- $\mathrm{H}_{2} \mathrm{O}_{\text {melt }}$ paths for the closed system crystallization of Qitianling mafic granite (QTL38C) in the temperature versus wt \% $\mathrm{H}_{2} \mathrm{O}$ in melt diagrams. The colored dashed lines represent different bulk water contents. The gray contoured lines in (b) show the wt \% of crystals, as inferred from mass balance calculations of run products (Table S4).

Magma $\mathrm{H}_{2} \mathrm{O}$ contents significantly lower than this value would result in a late saturation of Amp, that is, below $\sim 725{ }^{\circ} \mathrm{C}$ for $2-3$ wt \% bulk $\mathrm{H}_{2} \mathrm{O}$, and in a largely interstitial texture of Amp (e.g., Clemens et al., 1986), which is not observed. This leads us to conclude that Qitianling magmas were rich in $\mathrm{H}_{2} \mathrm{O}$ very early in their evolution (i.e., $\geq 4 \mathrm{wt} \% \mathrm{H}_{2} \mathrm{O}_{\text {melt }}$ near liquidus), which is at the high end of the range inferred by Clemens et al. (1986) for the A-type Watergums granite, but similar to that determined for other A-type felsic magmas (e.g., Bogaerts et al., 2006; Dall'Agnol et al., 1999), including peralkaline compositions (Scaillet \& Macdonald, 2001). It is worth noting that for the intermediate Phase 2 composition, $8 \mathrm{wt} \% \mathrm{H}_{2} \mathrm{O}_{\text {melt }}$ are required to crystallize Amp (Figure 3). Although our data support derivation of Phase 2 from Phase 1 crystallization (see section 5.3 below), direct production of Phase 2 granite by partial melting in the deep crust cannot be excluded. In such a case, the same reasoning used for Phase 1 (Figure 9) would imply that very high water contents ( $\geq 8 \mathrm{wt} \%$ ) are needed during source melting to produce Phase 2 type granites.

The high initial melt $\mathrm{H}_{2} \mathrm{O}$ contents may relate to dehydration partial melting of hydrous source minerals such as Amp and Bt, which may yield initial $\mathrm{H}_{2} \mathrm{O}_{\text {melt }}$ of up to $~ 9 \mathrm{wt} \%$ with melt compositions broadly similar to Qitianling mafic magmas (e.g., Beard \& Lofgren, 1991). In addition, fluids derived from mantle-derived magmas underplated in the lower crust, which are inferred to have provided most of the heat for generating the crustal melts and Jurassic granites in South China (e.g., Li et al., 2006, 2007; Zhao et al., 2012), could have played a role as well, though such fluids would have been $\mathrm{CO}_{2}$-rich, while we infer low $\mathrm{CO}_{2}$ contents for the main granite magmas with $\mathrm{XH}_{2} \mathrm{O}>0.7$ during most of its crystallization (compare Figures 3 and 9). Based on the composition of the natural Bt crystals, melt fluorine contents appear to have been $\sim 0.2 \mathrm{wt} \%$ and thus moderately high during Bt crystallization (using a $\left(D_{\mathrm{F}}{ }^{\mathrm{Bt} / \mathrm{melt}}\right)$ partition coefficient of 3.7 according to Icenhower and London (1997), but significantly below saturation (at several wt \%; Bailey, 1977; Huang et al., 2015) until late-stage crystallization. The fact that experimental Amps also have similar F contents than their natural counterparts further shows that $\mathrm{F}$ content in the experiments was similar to that in the magma (Table S7). Altogether, this suggests that fluorine role on phase equilibria is well accounted for in our experiments. Melt chlorine contents appear to have been $\sim 0.1 \mathrm{wt} \%$ and thus also low during Bt crystallization (if we assume a partition coefficient $\left(D_{\mathrm{Cl}}{ }^{\mathrm{Bt} / \mathrm{melt}}\right)$ of 2.9 from Icenhower \& London, 1997). We note that the $\mathrm{Cl}$ contents of our experimental Bt crystals are lower than those of the natural crystals, which likely indicates that, unlike $\mathrm{F}, \mathrm{Cl}$ was lost during starting material preparation (fusion at in 1 bar). Altogether, the Amp and $\mathrm{Bt}$ record thus indicates that near liquidus $\mathrm{F}$ and $\mathrm{Cl}$ contents have been quite low, below $0.1 \mathrm{wt} \%$.

\subsubsection{Oxygen Fugacity}

Mag is the only oxide in our NNO+2.4 experiments, while Mag and Ilm coexist in the natural samples, ruling out that the natural magmas crystallized at very oxidizing conditions. In our reducing experiments at 
$\sim \mathrm{NNO}-1.3$, both Ilm and Mag coexist at $\leq 850^{\circ} \mathrm{C}$. The composition of Amp and Bt, and in particular their $\mathrm{Fe} / \mathrm{Mg}$ ratios, are also well reproduced in our reduced runs at near solidus temperatures (Figures 6 and 7), suggesting similarly low $\mathrm{fO}_{2}$. A slightly lower $\mathrm{fO}_{2}$ (e.g., $\geq \mathrm{NNO}-1.3$ ), however, likely prevailed in the natural system, which would have displaced the stability field of Amp downward in a $\mathrm{T}-\mathrm{H}_{2} \mathrm{O}_{\text {melt }}$ projection, such that Amp replaced Cpx at near solidus and $\mathrm{H}_{2} \mathrm{O}$-rich crystallization conditions at $~ 300-350 \mathrm{MPa}$ (cf. Dall'Agnol et al., 1999; Table S4). While Ttn has been found in evolved magmas crystallized at oxidizing conditions ( NNO +2.5; e.g., Dall'Agnol et al., 1999), it is also present in our experiments performed at relatively reducing conditions ( NNO-1.3) at 300 and $400 \mathrm{MPa}$, at $\leq 700{ }^{\circ} \mathrm{C}$, and at $\mathrm{H}_{2} \mathrm{O}$ saturation (see also Xirouchakis \& Lindsley, 1998). Taken together, our results thus suggest that the Qitianling magma(s) evolved at redox conditions around NNO-1.3 \pm 0.5 . This range is lower than that calculated for our Bt compositions following the calculation scheme of Wones and Eugster (1965) and that inferred by Zhao et al. (2005) based on calculated Bt $\mathrm{Fe}^{2+} / \mathrm{Fe}^{3+}$ composition: the estimated $\mathrm{fO}_{2}$ with this method ranges between the NNO and the MH buffers. We however note that redox conditions may have increased during subsolidus cooling, that is, during hydrothermal alteration. In support of this are the Fe-Ti oxide compositions, which indicate an $\mathrm{fO}_{2}$ around NNO +1 and equilibration around $580^{\circ} \mathrm{C}$. How the Qitianling rocks were oxidized needs to be further investigated, but late volatile exsolution and loss is a possible factor (e.g., Candela, 1986).

\subsection{Geochemical Evolution of the Qitianling Magmas}

Previous work has suggested that the Phase 1 to Phase 3 granites of the Qitianling pluton are related by fractionation at the emplacement level, by fractionation at deeper level, or by variation in source partial melting (Liu et al., 2018; Zhu et al., 2009). The glass compositions produced in our experiments provide the following constraints: First, liquids obtained from the crystallization of our most mafic starting material, (the Phase 1 composition, QTL38C), match the composition of the Phase 2 granites at temperatures of $\sim 900$ to $850{ }^{\circ} \mathrm{C}$ and the composition of the most evolved, Phase 3, granites at temperatures of $\leq 750{ }^{\circ} \mathrm{C}$ (Figure 10a, Table S10). Residual liquids from Phase 2 experiments at $\leq 700{ }^{\circ} \mathrm{C}$ equally match the most evolved whole-rock compositions of the pluton. This indicates that the more evolved rocks of the pluton (i.e., Phase 2 and/or Phase 3 granites) may represent low-temperature differentiates of magmas equivalent to the Phase 2 and/or Phase 1 whole-rock compositions. Second, that compositions with $<\sim 68 \mathrm{wt} \% \mathrm{SiO}_{2}$ were not reproduced is due to the fact that we did not explore temperatures higher than $900{ }^{\circ} \mathrm{C}$, which would have produced crystalpoorer run products with lower-SiO $\mathrm{S}_{2}$ glass compositions. Experiments at $950{ }^{\circ} \mathrm{C}$ would presumably extend the experimental trend toward more mafic compositions, approaching the bulk composition of our starting materials, hence reproducing the entire natural compositional field. Third, the effect of variable pressure and $\mathrm{H}_{2} \mathrm{O}_{\text {melt }}$ on experimental liquids is subtle, but nevertheless significant for the range explored. In particular, at $200 \mathrm{MPa}$, liquid $\mathrm{CaO}$ contents are notably lower and the liquid $\mathrm{K}_{2} \mathrm{O}$ contents are notably higher than for liquids produced at $\geq 300 \mathrm{MPa}$ (Figures $8 \mathrm{~g}-8 \mathrm{i}$ for $\mathrm{CaO}$ and Figures $8 \mathrm{~d}-8 \mathrm{f}$ for $\mathrm{K}_{2} \mathrm{O}$ ). The glasses produced at $300 \mathrm{MPa}$ closely approximate the natural whole-rock compositional trends, thus suggesting that the granitic magmas fractionated at or close to the level of final emplacement and crystallization (Figures 8 and S3). This provides a key constraint for previously proposed models of evolution (Liu et al., 2018), suggesting that incrementally emplaced magmas did not fractionate at significantly deeper levels than those exposed (their Model 2), but in situ (their Model 1) or at least within the lopolith-like intrusion.

If such shallow fractionation took place, then mafic cumulates should be present, but they are not exposed. Granitoid rocks more mafic than those exposed in the Qitianling pluton do, however, exist in the nearby Jurassic Huashan pluton, which crops out $200 \mathrm{~km}$ southwest of the Qitianling pluton. The Huashan pluton is compositionally and mineralogically similar to Qitianling (Feng et al., 2012), except for the occurrence of more mafic varieties (the Niumiao unit with 58-60 wt \% $\mathrm{SiO}_{2}, \sim 14 \mathrm{wt} \% \mathrm{Al}_{2} \mathrm{O}_{3}, \sim 7 \mathrm{wt} \% \mathrm{FeO}, \sim 5-6 \mathrm{wt} \% \mathrm{CaO}$, $\sim 3$ wt $\% \mathrm{Na}_{2} \mathrm{O}$, and $\sim 4$ wt $\% \mathrm{~K}_{2} \mathrm{O}$ ), which extends the Qitianling whole-rock compositional trends toward more mafic compositions (Figure 10). These mafic rocks could represent the cumulate counterparts, which at Qitianling would be present at a level below exposure.

If the granites fractionated in situ and if the exposed granites represent one of multiple, subhorizontally emplaced magma sheets (Model 1 of Liu et al., 2018), then the large spread of zircon crystallization ages, from $\sim 163$ to $\sim 146 \mathrm{Ma}$, remains to be interpreted. Published data of Zhu et al. (2009) suggest that the studied Phase 1 granites ( 163-160 Ma) are slightly older than the Phase 2 granites ( 157-153 Ma), although these age relations need to be confirmed, especially as most ages overlap within the uncertainty of the methods. 

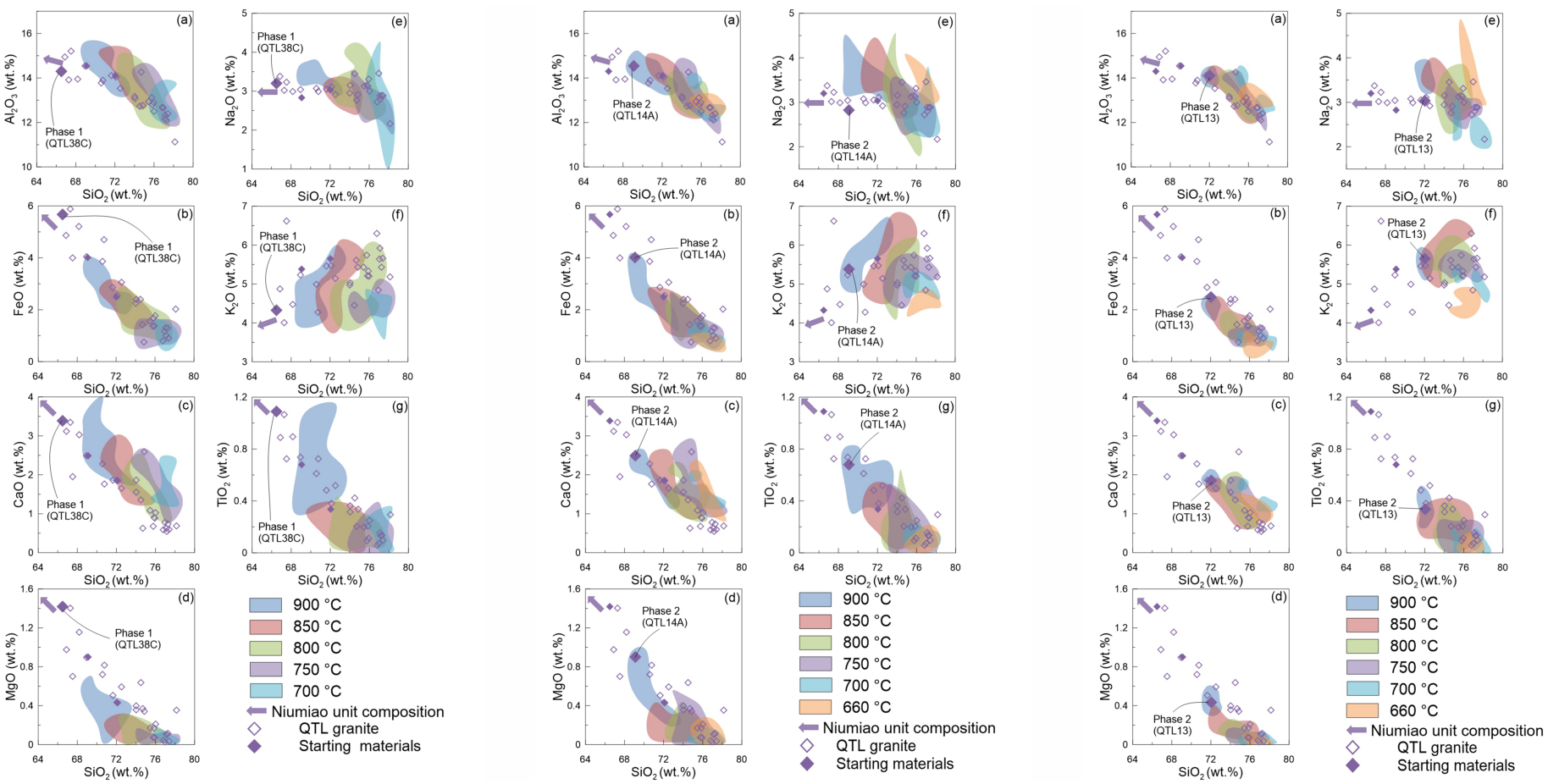

Figure 10. (middle two columns) Whole-rock compositions of the Qitianling granites $(\diamond)$ and starting materials ( $\diamond$ ) (totals normalized to $100 \mathrm{wt} \%$ ) compared to residual glass compositions from the Phase 1 (QTL38C, left two columns) and the Phase 2 (QTL14A, middle two columns and QTL13, right two columns) experiments (QTL38C). The Niumiao unit compositions are from Feng et al. (2012).

The Phase 3 granites, which we did not study in detail, appear significantly younger than the Phase 1 and Phase 2 granites with ages of $\sim 149-146 \mathrm{Ma}$. They could represent evolved liquids extracted from magma mush, which either retained a small liquid fraction for an extended period of time (warm storage models; e.g., Barboni et al., 2016), or which was repeatedly reheated and partly defrosted by the emplacement of new increments of magma (cold storage models; e.g., Cooper \& Kent, 2014). The young ages could, however, also be partly reset as they were acquired on U-rich zircon (Zhu et al., 2009). Whatever, thermal simulations (e.g., Annen et al., 2015) show that the exposed whole mass of the Qitianling pluton cannot have remained as a liquid/mush magma body for such an extended period of time ( $\geq 17 \mathrm{Ma}$ ). Such a long time interval more likely records the pulsatory nature of magma delivery in upper crust, possibly via a dyking mechanism (e.g., Clemens \& Mawer, 1992), in large part reflecting the time period during which the lower crust was partially melted (Annen et al., 2006). Each magma batch once intruded cooled and fractionated to some extent, producing part of the chemical array nowadays preserved by the rocks. The general coherence of the suite shows that each new magma addition had broadly the same geochemical characteristic than those early emplaced.

\section{Conclusions}

The combination of constraints from phase equilibrium experiments with field- and micro-scale observations and whole-rock and mineral chemical data show that the main Qitianling A-type granite in South China crystallized from hot $\left(>900{ }^{\circ} \mathrm{C}\right)$, initially $\mathrm{H}_{2} \mathrm{O}$-rich $(\geq 4 \mathrm{wt} \%$ ), and moderately reducing (at $\sim \mathrm{NNO}$ $-1.3 \pm 0.5$ ) magmas that were emplaced at $\geq 300-350 \mathrm{MPa}$ (at a depth of $\geq 10-12 \mathrm{~km}$ ), where they fractionated up to reaching $\mathrm{H}_{2} \mathrm{O}_{\text {melt }} \geq 6.5-8.0 \mathrm{wt} \%$ close to solidus. This highlights that crustal sources were $\mathrm{H}_{2} \mathrm{O}$-rich, yet also reached high temperature, which in combination must have favored the formation of large volumes of granitic magmas in the Jurassic. We stress that our phase equilibrium results were critical for constraining magmatic $\mathrm{H}_{2} \mathrm{O}$ content, but also for robustly and accurately constraining amphibole crystallization temperature and magma redox state, while available thermometers and oxybarometers do 


\section{Acknowledgments}

This study was supported financially by the Natural Science Foundation of China (Grants 41230315, 41572045 and 41611130111) and CNRS-NSFCPRC1209, Equipex PLANEX ANR-11EQPX-0036, Labex VOLTAIRE ANR10-LABX-100-01 of France. We also gratefully acknowledge financial support by China Scholarship Council. W. L. Zhang and I. Di Carlo are thanked for their kind help with EPMA analyses and S. Janiec and P. Benoist are thanked for the thin section preparation and SEM assistance. R. Champallier and J. Andújar are thanked for their help with IHPV experiments. We would like to sincerely thank M. Pichavant for many stimulating discussions. We have benefited from the detailed and constructive reviews of A. Castro and an anonymous reviewer. The Editor $\mathrm{S}$. Parman is thanked for providing editorial guidance. Our supporting information tables (raw data) and figures associated with this article are available at Figshare (https://doi.org/ 10.6084/m9.figshare.9728393). not perform well for ferroan A-type granites crystallized at $<\mathrm{NNO}+1$. Our results support the view that Qitianling magmas fractionated at or near the level of their final emplacement and crystallization (i.e., at a depth of $\geq 10-12 \mathrm{~km}$ ).

\section{References}

Ackerson, M. R., Mysen, B. O., Tailby, N. D., \& Watson, E. B. (2018). Low-temperature crystallization of granites and the implications for crustal magmatism. Nature, 559(7712), 94-97. https://doi.org/10.1038/s41586-018-0264-2

Anderson, J. L. (1996). Status of thermobarometry in granitic batholiths. Transactions of the Royal Society of Edinburgh: Earth Sciences, 87(1-2), 125-138. https://doi.org/10.1017/S0263593300006544

Anderson, J. L., Barth, A. P., Wooden, J. L., \& Mazdab, F. (2008). Thermometers and thermobarometers in granitic systems. Reviews in Mineralogy and Geochemistry, 69(1), 121-142. https://doi.org/10.2138/rmg.2008.69.4

Anderson, J. L., \& Smith, D. R. (1995). The effects of temperature and $\mathrm{fo}_{2}$ on the Al-in-hornblende barometer. American Mineralogist, 80(5-6), 549-559. https://doi.org/10.2138/am-1995-5-614

Andújar, J., \& Scaillet, B. (2012). Relationships between pre-eruptive conditions and eruptive styles of phonolite-trachyte magmas. Lithos, 152, 122-131. https://doi.org/10.1016/j.lithos.2012.05.009

Annen, C., Blundy, J., \& Sparks, R. (2006). The genesis of intermediate and silicic magmas in deep crustal hot zones. Journal of Petrology, 47(3), 505-539. https://doi.org/10.1093/petrology/egi084

Annen, C., Blundy, J. D., Leuthold, J., \& Sparks, R. S. J. (2015). Construction and evolution of igneous bodies: Towards an integrated perspective of crustal magmatism. Lithos, 230, 206-221.

Bailey, J. C. (1977). Fluorine in granitic rocks and melts: A review. Chemical Geology, 19(1-4), 1-42. https://doi.org/10.1016/0009-2541(77) 90002-X

Barboni, M., Boehnke, P., Schmitt, A. K., Harrison, T. M., Shane, P., Bouvier, A. S., \& Baumgartner, L. (2016). Warm storage for arc magmas Proceedings of the National Academy of Sciences, 113(49), 13,959-13,964.

Beard, J. S., \& Lofgren, G. E. (1991). Dehydration melting and water-saturated melting of basaltic and andesitic greenstones and amphibolites at 1, 3, and 6. 9 kb. Journal of Petrology, 32(2), 365-401. https://doi.org/10.1093/petrology/32.2.365

Bogaerts, M. (2003). Pétrologie expérimentale, géochimie et dynamique de mise en place dumassif de Lyngdal (Norvège): implications pour le magmatisme AMCG. (PhD thesis), 1-292. (in French with English abstract)

Bogaerts, M., Scaillet, B., \& Auwera, J. V. (2006). Phase equilibria of the Lyngdal granodiorite (Norway): Implications for the origin of metaluminous ferroan granitoids. Journal of Petrology, 47(12), 2405-2431. https://doi.org/10.1093/petrology/egl049

Cadoux, A., Scaillet, B., Druitt, T. H., \& Deloule, E. (2014). Magma storage conditions of large Plinian eruptions of Santorini Volcano (Greece). Journal of Petrology, 55(6), 1129-1171. https://doi.org/10.1093/petrology/egu021

Campbell, I. H., \& Griffiths, R. W. (1990). Implications of mantle plume structure for the evolution of flood basalts. Earth and Planetary Science Letters, 99(1-2), 79-93. https://doi.org/10.1016/0012-821X(90)90072-6

Candela, P. A. (1986). The evolution of aqueous vapor from silicate melts: Effect on oxygen fugacity. Geochimica et Cosmochimica Acta, 50(6), 1205-1211. https://doi.org/10.1016/0016-7037(86)90403-5

Chaussard, E., \& Amelung, F. (2014). Regional controls on magma ascent and storage in volcanic arcs. Geochemistry, Geophysics, Geosystems, 15, 1407-1418. https://doi.org/10.1002/2013GC005216

Chen, J., Wang, R., Zhu, J., Lu, J., \& Ma, D. (2013). Multiple-aged granitoids and related tungsten-tin mineralization in the Nanling Range, South China. Science China Earth Sciences, 56(12), 2045-2055. https://doi.org/10.1007/s11430-013-4736-9

Chu, Y., Lin, W., Faure, M., Wang, Q., \& Ji, W. (2012). Phanerozoic tectonothermal events of the Xuefengshan Belt, central South China: Implications from $\mathrm{U} / \mathrm{Pb}$ age and $\mathrm{Lu} / \mathrm{Hf}$ determinations of granites. Lithos, 150, 243-255. https://doi.org/10.1016/j.lithos.2012.04.005

Clemens, J. D., Holloway, J. R., \& White, A. J. R. (1986). Origin of an A-type granite: experimental constraints. American Mineralogist, 71, 317-324.

Clemens, J. D., \& Mawer, C. K. (1992). Granitic magma transport by fracture propagation. Tectonophysics, 204(3-4), 339-360. https://doi. org/10.1016/0040-1951(92)90316-X

Clemens, J. D., \& Wall, V. J. (1981). Origin and crystallization of some peraluminous (S-type) granitic magmas. Canadian Mineralogist, 19(1), 111-131.

Collins, W. J., Huang, H. Q., \& Jiang, X. (2016). Water-fluxed crustal melting produces cordilleran batholiths. Geology, 44, G37398.1.

Cooper, K. M., \& Kent, A. J. (2014). Rapid remobilization of magmatic crystals kept in cold storage. Nature, 506(7489), 480.

Dall'Agnol, R., Scaillet, B., \& Pichavant, M. (1999). An experimental study of a lower proterozoic A-type granite from the eastern Amazonian craton, Brazil. Journal of Petrology, 40(11), 1673-1698. https://doi.org/10.1093/petroj/40.11.1673

Defant, M. J., \& Drummond, M. S. (1990). Derivation of some modern arc magmas by melting of young subducted lithosphere. Nature, 347(6294), 662-665. https://doi.org/10.1038/347662a0

Deng, X. G., Li, X. H., Liu, Y. M., Huang, G. F., \& Hou, M. S. (2005). Geochemical characteristics of Qitianling granites and their implications for mineralization. Yanshi Kuangwuxue Zazhi (Acta Petrology and Mineralogy), 24(2), 93-102. (in Chinese with English abstract)

Erdmann, S., Martel, C., Pichavant, M., \& Kushnir, A. (2014). Amphibole as an archivist of magmatic crystallization conditions: problems, potential, and implications for inferring magma storage prior to the paroxysmal 2010 eruption of Mount Merapi, Indonesia. Contributions to Mineralogy and Petrology, 167(6), 1016.

Faure, M., Lepvrier, C., Nguyen, V. V., Vu, T. V., Lin, W., \& Chen, Z. (2014). The South China Block-Indochina collision: Where, when, and how? Journal of Asian Earth Sciences, 79, 260-274. https://doi.org/10.1016/j.jseaes.2013.09.022

Faure, M., Lin, W., Monié, P., \& Meffre, S. (2008). Palaeozoic collision between the North and South China blocks, Triassic intracontinental tectonics, and the problem of the ultrahigh-pressure metamorphism. Comptes Rendus Geoscience, 340(2-3), 139-150. https://doi.org/ 10.1016/j.crte.2007.10.007

Feng, Z., Wang, C., Zhang, M., \& Liang, J. (2012). Unusually dumbbell-shaped Guposhan-Huashan twin granite plutons in Nanling Range of south China: Discussion on their incremental emplacement and growth mechanism. Journal of Asian Earth Sciences, 48, 9-23. https:// doi.org/10.1016/j.jseaes.2011.12.022

Hammarstrom, J. M., \& Zen, E. A. (1986). Aluminum in hornblende: An empirical igneous geobarometer. American Mineralogist, 71(11-12), 1297-1313.

He, Z. Y., Xu, X. S., \& Niu, Y. (2010). Petrogenesis and tectonic significance of a Mesozoic granite-syenite-gabbro association from inland South China. Lithos, 119(3-4), 621-641. https://doi.org/10.1016/j.lithos.2010.08.016 
Holland, T., \& Blundy, J. (1994). Non-ideal interactions in calcic amphiboles and their bearing on amphibole-plagioclase thermometry. Contributions to Mineralogy and Petrology, 116(4), 433-447. https://doi.org/10.1007/BF00310910

Hollister, L. S., Grissom, G. C., Peters, E. K., Stowell, H. H., \& Sisson, V. B. (1987). Confirmation of the empirical correlation of Al in hornblende with pressure of solidification of calc-alkaline plutons. American Mineralogist, 72(3), 231-239.

Holtz, F., Johannes, W., Tamic, N., \& Behrens, H. (2001). Maximum and minimum water contents of granitic melts generated in the crust: A re-evaluation and implications. Lithos, 56(1), 1-14. https://doi.org/10.1016/S0024-4937(00)00056-6

Hua, R. M., Chen, P. R., Zhang, W. L., \& Lu, J. J. (2005). Three major metallogenic events in Mesozoic in South China. Mineral Deposits, 24(2), 99-107. (in Chinese with English abstract)

Huang, F. F., Wang, R. C., Xie, L., Zhu, J. C., Erdmann, S., Che, X. D., \& Zhang, R. Q. (2015). Differentiated rare-element mineralization in an ongonite-topazite composite dike at the Xianghualing tin district, southern china: An electron-microprobe study on the evolution from niobium-tantalum-oxides to cassiterite. Ore Geology Reviews, 65(3), 761-778. https://doi.org/10.1016/j.oregeorev.2014.08.008

Icenhower, J. P., \& London, D. (1997). Partitioning of fluorine and chlorine between biotite and granitic melt: Experimental calibration at 200 MPa H 2 O. Contributions to Mineralogy and Petrology, 127(1-2), 17-29. https://doi.org/10.1007/s004100050262

Johannes, W., \& Holtz, F. (1990). Formation and composition of $\mathrm{H}_{2} \mathrm{O}$-undersaturated granitic melts. In High-temperature metamorphism and crustal anatexis (pp. 87-104). Dordrecht: Springer. https://doi.org/10.1007/978-94-015-3929-6_4

Johnson, M. C., \& Rutherford, M. J. (1989). Experimental calibration of the aluminum-in-hornblende geobarometer with application to Long Valley caldera (California) volcanic rocks. Anaesthesia, 56(2), 195-195.

Klimm, K., Holtz, F., Johannes, W., \& King, P. L. (2003). Fractionation of metaluminous A-type granites: An experimental study of the Wangrah suite, Lachlan fold belt, Australia. Precambrian Research, 124(2-4), 327-341. https://doi.org/10.1016/S0301-9268(03)00092-5

Klimm, K., Holtz, F., \& King, P. L. (2008). Fractionation vs. magma mixing in the Wangrah suite A-type granites, Lachlan fold belt, Australia: experimental constraints. Lithos, 102(3-4), 415-434. https://doi.org/10.1016/j.lithos.2007.07.018

Leake, B. E., Wooley, A. R., Arps, C. E. S., Birch, W. D., Gilbert, M. C., Grice, J. D., et al. (1997). Nomenclature of amphiboles; report of the subcommittee on amphiboles of the international mineralogical association commission on new minerals and mineral names. American Mineralogist, 82(9), 1019-1037.

Leake, B. E., Woolley, A. R., Birch, W. D., Burke, E. A., Ferraris, G., Grice, J. D., et al. (2003). Nomenclature of amphiboles: Additions and revisions to the International Mineralogical Association's 1997 recommendations. The Canadian Mineralogist, 41(6), 1355-1362. https:// doi.org/10.2113/gscanmin.41.6.1355

Li, Z. L., Hu, R. Z., Peng, J. T., Bi, X. W., \& Li, X. M. (2006). Helium isotope geochemistry of ore-forming fluids from Furong tin ore field in Hunan Province, China. Resource Geology, 56(1), 9-15. https://doi.org/10.1111/j.1751-3928.2006.tb00263.x

Li, Z. L., Hu, R. Z., Yang, J. S., Peng, J. T., Li, X. M., \& Bi, X. W. (2007). He, Pb and S isotopic constraints on the relationship between the Atype Qitianling granite and the Furong tin deposit, Hunan province, China. Lithos, 97(1-2), 161-173. https://doi.org/10.1016/j. lithos.2006.12.009

Li, Z. X., \& Li, X. H. (2007). Formation of the 1300-km-wide intracontinental orogen and post-orogenic magmatic province in Mesozoic South China: A flat-slab subduction model. Geology, 35(2), 179-182. https://doi.org/10.1130/G23193A.1

Liu, H., Martelet, G., Wang, B., Erdmann, S., Chen, Y., Faure, M., et al. (2018). Incremental emplacement of the Late Jurassic midcrustal, lopolith-like Qitianling Pluton, South China, Revealed by AMS and Bouguer Gravity Data. Journal of Geophysical Research: Solid Earth, 123, 9249-9268. https://doi.org/10.1029/2018JB015761

Mahood, G. A. (1984). Pyroclastic rocks and calderas associated with strongly peralkaline magmatism. Journal of Geophysical Research, 89(B10), 8540-8552. https://doi.org/10.1029/JB089iB10p08540

Mao, J. W., Chen, Y. B., Chen, M. H., \& Franco, P. (2013). Major types and time-space distribution of Mesozoic ore deposits in South China and their geodynamic settings. Mineralium Deposita, 48(3), 267-294.

Mao, J. W., Xie, G. Q., Li, X. F., Zhang, C. Q., \& Wang, Y. T. (2010). Mesozoic large-scale mineralization and multiple lithospheric extensions in South China. Acta Geologica Sinica-English Edition, 80(3), 420-431.

Morimoto, N. (1988). Nomenclature of pyroxenes. Mineralogy and Petrology, 39(1), 55-76. https://doi.org/10.1007/BF01226262

Mutch, E. J. F., Blundy, J. D., Tattitch, B. C., Cooper, F. J., \& Brooker, R. A. (2016). An experimental study of amphibole stability in lowpressure granitic magmas and a revised Al-in-hornblende geobarometer. Contributions to Mineralogy and Petrology, 171(10), 85. https:// doi.org/10.1007/s00410-016-1298-9

Naney, M. T. (1983). Phase equilibria of rock-forming ferromagnesian silicates in granitic systems. American Journal of Science, 283(10), 993-1033. https://doi.org/10.2475/ajs.283.10.993

Newman, S., \& Lowenstern, J. B. (2002). VolatileCalc: A silicate melt- $\mathrm{H}_{2} \mathrm{O}-\mathrm{CO}_{2}$ solution model written in Visual Basic for excel. Computers \& Geosciences, 28(5), 597-604. https://doi.org/10.1016/S0098-3004(01)00081-4

Pichavant, M. (1987). Effects of $\mathrm{B}$ and $\mathrm{H}_{2} \mathrm{O}$ on liquidus phase relations in the haplogranite system at 1 kbar. American Mineralogist, 72(11-12), 1056-1070.

Pichavant, M., Costa, F., Burgisser, A., Scaillet, B., Martel, C., \& Poussineau, S. (2007). Equilibration scales in silicic to intermediate magmas-implications for experimental studies. Journal of Petrology, 48(10), 1955-1972. https://doi.org/10.1093/petrology/egm045

Putirka, K. (2016). Amphibole thermometers and barometers for igneous systems and some implications for eruption mechanisms of felsic magmas at arc volcanoes. American Mineralogist, 101(4), 841-858. https://doi.org/10.2138/am-2016-5506

Qi, L., Hu, J., \& Gregoire, D. C. (2000). Determination of trace elements in granites by inductively coupled plasma mass spectrometry. Talanta, 51(3), 507-513.

Rieder, M., Cavazzini, G., D'yakonov, Y. S., Frank-Kamenetskii, V. A., Gottardi, G., Guggenheim, S., et al. (1998). Nomenclature of the micas. Clays and Clay Minerals, 46(5), 586-595. https://doi.org/10.1346/CCMN.1998.0460513

Scaillet, B., \& Evans, B. W. (1999). The 15 June 1991 eruption of Mount Pinatubo. I. Phase equilibria and pre-eruption P-T-fO $\mathrm{P}_{2}-f \mathrm{H}_{2} \mathrm{O}$ conditions of the dacite magma. Journal of Petrology, 40(3), 381-411. https://doi.org/10.1093/petroj/40.3.381

Scaillet, B., Holtz, F., \& Pichavant, M. (1998). Phase equilibrium constraints on the viscosity of silicic magmas: 1. Volcanic-plutonic comparison. Journal of Geophysical Research, 103(B11), 27,257-27,266. https://doi.org/10.1029/98JB02469

Scaillet, B., Holtz, F., \& Pichavant, M. (2016). Experimental constraints on the formation of silicic magmas. Elements, 12(2), 109-114. https://doi.org/10.2113/gselements.12.2.109

Scaillet, B., \& Macdonald, R. A. Y. (2001). Phase relations of peralkaline silicic magmas and petrogenetic implications. Journal of Petrology, 42(4), 825-845. https://doi.org/10.1093/petrology/42.4.825

Scaillet, B., Pichavant, M., \& Roux, J. (1995). Experimental crystallization of leucogranite magmas. Journal of Petrology, 36(3), 663-705. https://doi.org/10.1093/petrology/36.3.663 
Scaillet, B., Pichavant, M., Roux, J., Humbert, G., \& Lefevre, A. (1992). Improvements of the Shaw membrane technique for measurement and control of $f \mathrm{H}_{2}$ at high-temperatures and pressures. American Mineralogist, 77(5), 647-655.

Schmidt, M. W. (1992). Amphibole composition in tonalite as a function of pressure: An experimental calibration of the Al-in-hornblende barometer. Contributions to Mineralogy and Petrology, 110(2-3), 304-310. https://doi.org/10.1007/BF00310745

Shu, L. S., Faure, M., Yu, J. H., \& Jahn, B. M. (2011). Geochronological and geochemical features of the Cathaysia block (South China): New evidence for the Neoproterozoic breakup of Rodinia. Precambrian Research, 187(3-4), 263-276. https://doi.org/10.1016/j. precamres.2011.03.003

Stormer, J. C. (1983). The effects of recalculation on estimates of temperature and oxygen fugacity from analyses of multicomponent irontitanium oxides. American Mineralogist, 68(5), 586-594.

Taylor, J. R., Wall, V. J., \& Pownceby, M. I. (1992). The calibration and application of accurate redox sensors. American Mineralogist, 77(3), 284-295.

Thompson, A. B., \& Connolly, J. A. (1995). Melting of the continental crust: Some thermal and petrological constraints on anatexis in continental collision zones and other tectonic settings. Journal of Geophysical Research, 100(B8), 15,565-15,579. https://doi.org/10.1029/ 95JB00191

Wang, R., Xie, L., Lu, J., Zhu, J., \& Chen, J. (2017). Diversity of Mesozoic tin-bearing granites in the Nanling and adjacent regions, South China: Distinctive mineralogical patterns. Science China Earth Sciences, 60(11), 1909-1919. https://doi.org/10.1007/s11430-017-9112-5

Wang, R. C., Xie, L., Chen, J., Yu, A., Wang, L., Lu, J., \& Zhu, J. (2013). Tin-carrier minerals in metaluminous granites of the western Nanling range (southern China): Constraints on processes of tin mineralization in oxidized granites. Journal of Asian Earth Sciences, 74(18), 361-372. https://doi.org/10.1016/j.jseaes.2012.11.029

Wang, X. L., Zhou, J. C., Griffin, W. A., Wang, R. C., Qiu, J. S., O'reilly, S. Y., et al. (2007). Detrital zircon geochronology of Precambrian basement sequences in the Jiangnan orogen: Dating the assembly of the Yangtze and Cathaysia Blocks. Precambrian Research, 159(1-2), 117-131. https://doi.org/10.1016/j.precamres.2007.06.005

Wang, X. L., Zhou, J. C., Qiu, J. S., Zhang, W. L., Liu, X. M., \& Zhang, G. L. (2006). LA-ICP-MS U-Pb zircon geochronology of the Neoproterozoic igneous rocks from Northern Guangxi, South China: Implications for tectonic evolution. Precambrian Research, 145(1-2), 111-130. https://doi.org/10.1016/j.precamres.2005.11.014

Wang, Y. J., Fan, W. M., Guo, F., Peng, T. P., \& Li, C. W. (2003). Geochemistry of mesozoic mafic rocks adjacent to the Chenzhou-Linwu fault, south China: Implications for the lithospheric boundary between the Yangtze and Cathaysia blocks. International Geology Review, 45(3), 263-286. https://doi.org/10.2747/0020-6814.45.3.263

Whitney, D. L., \& Evans, B. W. (2010). Abbreviations for names of rock-forming minerals. American Mineralogist, 95(1), 185-187. https:// doi.org/10.2138/am.2010.3371

Wones, D. R., \& Eugster, H. P. (1965). Stability of biotite: experiment, theory, and application. American Mineralogist: Journal of Earth and Planetary Materials, 50(9), 1228-1272.

Xia, Y., Xu, X., Zou, H., \& Liu, L. (2014). Early Paleozoic crust-mantle interaction and lithosphere delamination in South China Block: Evidence from geochronology, geochemistry, and Sr-Nd-Hf isotopes of granites. Lithos, 184, 416-435.

Xie, L., Wang, R., Chen, J., Zhu, J., Zhang, W., Lu, J., \& Zhang, R. (2013). A tin-mineralized topaz rhyolite dike with coeval topaz granite enclaves at Qiguling in the Qitianling tin district, southern China. Lithos, 170, 252-268.

Xie, L., Wang, R., Chen, J., Zhu, J., Zhang, W., Wang, D., \& Yu, A. (2009). Primary Sn-rich titianite in the Qitianling granite, Hunan Province, southern China: An important type of tin-bearing mineral and its implications for tin exploration. Chinese Science Bulletin, 54(5), 798-805.

Xie, L., Wang, R. C., Chen, J., \& Zhu, J. C. (2010). Mineralogical evidence for magmatic and hydrothermal processes in the Qitianling oxidized tin-bearing granite (Hunan, South China): EMP and (MC)-LA-ICPMS investigations of three types of titanite. Chemical Geology, 276(1-2), 53-68. https://doi.org/10.1016/j.chemgeo.2010.05.020

Xirouchakis, D., \& Lindsley, D. H. (1998). Equilibria among titanite, hedenbergite, fayalite, quartz, ilmenite, and magnetite: experiments and internally consistent thermodynamic data for titanite. American Mineralogist, 83(7-8), 712-725. https://doi.org/10.2138/am-1998-7-804

Zhang, G., Guo, A., Wang, Y., Li, S., Dong, Y., Liu, S., et al. (2013). Tectonics of South China continent and its implications. Science China Earth Sciences, 56(11), 1804-1828. https://doi.org/10.1007/s11430-013-4679-1

Zhao, K., Xu, X., \& Erdmann, S. (2017). Crystallization conditions of peraluminous charnockites: Constraints from mineral thermometry and thermodynamic modelling. Contributions to Mineralogy and Petrology, 172(5), 26. https://doi.org/10.1007/s00410-017-1344-2

Zhao, K., Xu, X., \& Erdmann, S. (2018). Thermodynamic modeling for an incrementally fractionated granite magma system: Implications for the origin of igneous charnockite. Earth and Planetary Science Letters, 499, 230-242. https://doi.org/10.1016/j.epsl.2018.07.039

Zhao, K. D., Jiang, S. Y., Jiang, Y. H., \& Wang, R. C. (2005). Mineral chemistry of the Qitianling granitoid and the Furong tin ore deposit in Hunan province, south China. European Journal of Mineralogy, 17(4), 635-648. https://doi.org/10.1127/0935-1221/2005/0017-0635

Zhao, K. D., Jiang, S. Y., Yang, S. Y., Dai, B. Z., \& Lu, J. J. (2012). Mineral chemistry, trace elements and Sr-Nd-Hf isotope geochemistry and petrogenesis of Cailing and Furong granites and mafic enclaves from the Qitianling batholith in the Shi-Hang zone, South China. Gondwana Research, 22(1), 310-324. https://doi.org/10.1016/j.gr.2011.09.010

Zhou, B. X., Sun, T., Shen, W., Shu, L., \& Niu, Y. (2006). Petrogenesis of Mesozoic granitoids and volcanic rocks in South China: A response to tectonic evolution. Episodes, 29(1), 26.

Zhu, J. C., Chen, J., Wang, R. C., Lu, J. J., \& Xie, L. (2008). Early Yanshanian NE trending Sn/W-bearing A-type granites in the westernmiddle part of the Nanling Mts region. Geological Journal of China Universities, 14, 16-21. (in Chinese with English abstract)

Zhu, J. C., Huang, G. F., Zhang, P. H., Li, F. C., \& Rao, B. (2003). On the emplacement age and material sources for the granites of Cailing superunit, Qitianling pluton, South Hunan Province. Geological Review, 49(3), 245-252. (in Chinese with English abstract)

Zhu, J. C., Wang, R. C., Zhang, P. H., Xie, C. F., Zhang, W. L., Zhao, K. D., et al. (2009). Zircon U-Pb geochronological framework of Qitianling granite batholith, middle part of Nanling Range, South China. Science in China Series D: Earth Sciences, 52(9), 1279-1294. https://doi.org/10.1007/s11430-009-0154-4

Zhu, J. C., Zhang, H., Xie, C. F., Zhang, P. H., \& Yang, C. (2005). Zircon SHRIMP UPb geochronology, petrology and geochemistry of the Zhujianshui granite, Qitianling pluton, southern Hunan Province. Geological Journal of China Universities, 11(3), 335-342. (in Chinese with English abstract)

\section{References From the Supporting Information}

Andersen, D. J. (1985). New (and final!) models for the Ti-magnetite/ilmenite geothermometer and oxygen barometer. In Abstracts of American Geophysical Union 1985 Spring Meeting. American Geophysical Union, 66, 416. 
Anderson, A. T. (1968). The oxygen fugacity of alkaline basalt and related magmas, Tristan da Cunha. American Journal of Science, 266(8), 704-727. https://doi.org/10.2475/ajs.266.8.704

Carmichael, I. S. E., \& Nicholls, J. (1967). Iron-titanium oxides and oxygen fugacities in volcanic rocks. Journal of Geophysical Research, 72(18), 4665-4687. https://doi.org/10.1029/JZ072i018p04665

Chou, I. M. (1987). Oxygen buffer and hydrogen sensor techniques at elevated pressures and temperatures. In Hydrothermal experimental techniques (pp. 61-99). New York: John Wiley.

Lepage, L. D. (2003). ILMAT: An excel worksheet for ilmenite-magnetite geothermometry and geobarometry. Computers \& Geosciences, 29(5), 673-678. https://doi.org/10.1016/S0098-3004(03)00042-6

Lindsley, D. H., \& Spencer, K. J. (1982). Fe-Ti oxide geothermometry: Reducing analyses of coexisting Ti-magnetite (Mt) and ilmenite (Ilm) Eos, Transactions of the American Geophysical Union, 63(18), 471.

Powell, R., \& Powell, M. (1977). Geothermometry and oxygen barometry using coexisting iron-titanium oxides: A reappraisal. Mineralogica Magazine, 41(318), 257-263. https://doi.org/10.1180/minmag.1977.041.318.14

Prouteau, G., \& Scaillet, B. (2003). Experimental constraints on the origin of the 1991 Pinatubo dacite. Journal of Petrology, 44(12), 2203-2241. https://doi.org/10.1093/petrology/egg075

Spencer, K. J., \& Lindsley, D. H. (1981). A solution model for coexisting iron-titanium oxides. American Mineralogist, 66(11-12), 1189-1201.

Watson, E. B., \& Harrison, T. M. (1983). Zircon saturation revisited: Temperature and composition effects in a variety of crustal magma types. Earth and Planetary Science Letters, 64(2), 295-304. https://doi.org/10.1016/0012-821X(83)90211-X 